UNIVERSIDADE DE SÃO PAULO

ESCOLA DE ENFERMAGEM

THAÍS BATONI GONÇALVES DE SOUZA

Religiosidade e envelhecimento: panorama dos idosos do município de São Paulo

Estudo SABE

São Paulo

2011 
Religiosidade e envelhecimento: panorama dos idosos do município de São Paulo

\section{Estudo SABE}

Dissertação apresentada ao Programa de PósGraduação em Saúde do Adulto - PROESA da Escola de Enfermagem da Universidade de São Paulo para a obtenção do título de mestre.

Área de Concentração:

Enfermagem na Saúde do Adulto

Orientadora:

Prof $^{a}$. Dr ${ }^{a}$. Yeda A. O. Duarte

São Paulo 
AUTORIZO A REPRODUÇÃO E DIVULGAÇÃO TOTAL OU PARCIAL DESTE TRABALHO, POR QUALQUER MEIO CONVENCIONAL OU ELETRÔNICO, PARA FINS DE ESTUDO E PESQUISA, DESDE QUE CITADA A FONTE.

Assinatura:

Thaís Batoni Gonçalves de Souza

Data:

Catalogação na Publicação (CIP) Biblioteca "Wanda de Aguiar Horta"

Escola de Enfermagem da Universidade de São Paulo

Souza, Thaís Batoni Gonçalves de Souza

Religiosidade e envelhecimento: panorama dos idosos do município de São Paulo - Estudo SABE / Thaís Batoni Gonçalves de Souza. -- São Paulo, 2011.

$102 \mathrm{p}$.

Dissertação (Mestrado) - Escola de Enfermagem da Universidade de São Paulo.

Orientadora: Profa. Dra. Yeda A. O. Duarte

Área de concentração: Enfermagem na Saúde do Adulto

1. Religião 2. Idosos 3. Envelhecimento I.Título. 
Nome: Souza, Thaís Batoni Gonçalves de

Título: Religiosidade e envelhecimento: panorama dos idosos do município de São Paulo - Estudo SABE

Dissertação apresentada à Escola de Enfermagem da Universidade de São Paulo, para obtenção do título de Mestre em Enfermagem.

Área de Concentração:

Enfermagem na Saúdo do Adulto.

Aprovado em:

\section{Banca Examinadora}

$\operatorname{Prof}(\mathrm{a}) . \operatorname{Dr}(\mathrm{a})$.

Instituição:

Julgamento:

Assinatura:

$\operatorname{Prof}(\mathrm{a}) . \operatorname{Dr}(\mathrm{a})$.

Instituição:

Julgamento:

Assinatura:

Prof(a). Dr(a).

Instituição:

Julgamento:

Assinatura:

Prof(a). Dr(a).

Instituição:

Julgamento:

Assinatura: 
Dedico essa dissertação às pessoas mais importantes da minha vida....

Aos meus amados pais, Caio e Elsa,

Ao meu amor, Gustavo, pelo apoio e paciência durante todos estes anos;

Ao meu querido filfo Matteo,

E ao meu avô, Rômulo, o qual tenho certeza que está orgulhoso de mim neste momento onde quer que esteja... 


\section{Agradecimentos}

A Deus, pela oportunidade de estar vivendo cada dia e por sempre olhar por mim.

Ao Guga, pela paciência, por estar ao meu lado e por entender meus momentos de ausência.

Ao meu amado Matteo, por me fazer querer ser sempre alguém melhor.

Aos meus pais, Caio e Elsa, por estarem torcendo sempre por mim e incentivando-me a nunca desistir.

À Professora Maria Lúcia Lebrão, por me dar a oportunidade de participar deste estudo.

À Professora Yeda, pelas orientações e ensinamentos durante estes anos.

Aos meus irmãos Caio, Leandro, NNatasha e Conrado, que sempre torceram por mim.

Às amigas Tatiana e Isabel, que aguentaram meu mau humor, apoiaram-me e estiveram comigo nos piores e melhores momentos.

Aos amigos Samira, Karina, Alessandra e Samuel, pelos anos de apoio e amizade.

Aos enfermeiros da Clínica Médica, Felícia, Samira, Rosângela, Nívea, Anna Cláudia, Fernanda, Michele, Carol, Janaína, Marta, Ângela e Rômulo, pelo carinho, apoio e auxílio.

Aos técnicos de enfermagem da Clínica Médica, que me apoiaram e incentivaram durante toda essa jornada.

A Flávia Maia pela diponibilidade e carinho e atenção.

À amiga Vanessa Bertassi, que esteve presente nas angústias e nas vitórias, lutando sempre comigo para mais esta conquista.

À Ligiana, pela paciência e análise dos dados.

A Ana Paula Zanelatto, Joyce Rovarotto e Myria Ribeiro, pela colaboração, torcida e apoio.

Às meninas da pós-graduação, em especial à Silvana, por todo o apoio, dedicação e eficiência no que fazem.

A Néa Miwa, pelo auxílio na elaboração e formatação dessa dissertação.

E a todos os idosos, que com sua sabedoria nos transmitem experiências e lições de vida. 
"Quando a velhice chegar, aceita-a, ama-a. Ela é abundante em prazeres se souberes amá-la. Os anos que vão gradualmente declinando estão entre os mais doces da vida de um homem. Mesmo quando tenhas alcançado o limite extremo dos anos, estes ainda reservam prazeres". 
Souza TBG. Religiosidade e envelhecimento: panorama religioso dos idosos do município de São Paulo - Estudo SABE [Dissertação]. São Paulo:

Universidade de São Paulo, Escola de Enfermagem, 2011.

\section{Resumo}

O Brasil é um país permeado pela diversidade religiosa e em relação aos idosos, a religião é reconhecida como fonte de apoio, pois ajuda a encontrar sentido em situações negativas, aceitar a si mesmo e a se aproximar de religiosos que podem oferecer apoio emocional e ajudá-los a encontrar sentido no sofrimento. Este estudo teve como objetivo conhecer o perfil religioso e a importância dada à religião pelos idosos residentes no município de São Paulo e sua associação com condições de saúde. É um estudo longitudinal, descritivo e exploratório, com abordagem quantitativa, que faz parte do Estudo SABE - Saúde, Bem estar e Envelhecimento, realizado com idosos no município de São Paulo, em 2000, que foram reentrevistados em 2006. Os dados foram coletados através de questionário padronizado, com a intenção de traçar o panorama religioso e a importância dada à religião pelas pessoas idosas. Foi utilizado o Qui-Quadrado de Pearson para as análises, ajustado pelo Rao Scott e o nível de confiança estabelecido foi de $95 \%$. Em 2000 foi obtida uma amostra de 2143 idosos e, em 2006, esta foi composta por 1115 idosos. A maioria dos idosos pertence a alguma religião tanto em 2000 (97,6\%) como em 2006 (98,0\%), e se concentram principalmente na religião católica, evangélica e espírita. Em relação ao gênero, os homens são predominantes nas religiões católica e judaica, enquanto há maior referência de mulheres entre os evangélicos/protestantes, espíritas e orientais/budistas. Quanto à idade entre os longevos, há maior proporção de católicos e uma queda entre aqueles que referiram não ter nenhuma religião com o passar dos anos $(2,4 \%$ em 2000 e 1,7\% em 2006). A maioria dos idosos refere um credo religioso, sendo predominante entre as mulheres ( $p=0,0000$ em 2000 e $p=0,0155$ em 2006) e entre os viúvos $(p=0,0426)$. O maior número de doenças e a pior condição de saúde foram relacionados principalmente aos idosos sem credo religioso. A importância atribuída à religião é maior entre as mulheres, os mais idosos, e aqueles que referem melhor condição de saúde. Apesar da importância atribuída à religião em $2000(88,8 \%)$, ela passa a ser mais relevante ainda em 2006 (92,7\%). A maioria dos idosos refere que encontra na religião fortalecimento $(89,3 \%)$, auxílio para enfrentar dificuldades $(87,2 \%)$ e que ela oferece total ou muito sentido a vida dos mesmos $(87,9 \%)$. Portanto, conclui-se que a religião tem se tornado cada vez mais importante para os idosos e tem sido identificada como fonte de apoio social e enfrentamento para as dificuldades da vida, além de significado de vida diante do processo de saúde e envelhecimento.

Palavras-chave: Religião. Idoso. Envelhecimento. 
Souza TBG. Religiosity and aging: religious landscape of the elderly in São Paulo - SABE Study [Dissertação]. São Paulo: São Paulo University, Nursing School, 2011.

\begin{abstract}
Brazil in a country permeated by religious diversity, and in relation to the elderly, religion is known as a source of support because it helps to find a way to face negative situations, accept themselves and approaching religious people who can offer emotional support and help them to find a meaning in suffering. The aim of this study was to know the religious profile and the importance given to religion by the elderly residents in São Paulo city- Brazil, and its association with health status. It's a longitudinal, descriptive and exploratory study, with quantitative approach, part of the SABE StudySaúde, Bem-estar e Envelhecimento- Health, Wellbeing and Aging, in English-, performed with elderly people in São Paulo in the year 2000 and again in 2006. Data were collected by a standard questionnaire, with the intention of mapping religious landscape and the importance given to religion by the elderly. For the analyses, Pearson's chi-square test, adjusted by Rao Scott, was used and the confidence level was $95 \%$. In 2000, the sample was composed by 2143 elderly and in 2006, by 1115 . Most seniors have any religion in $2000(97,6 \%)$ and in $2006(98,0 \%)$. Catholicism, Spiritualism and Evangelical are the main religions. In relation to gender, men are predominant in Catholicism and Judaism and women are the majority in Evangelical, Spiritualism and Buddhism/Oriental religions. In relation to age, among the oldest old, there is a higher proportion of Catholics, and decrease of those that reported having no religion over the years $(2,4 \%$ in 2000 e $1,7 \%$ in 2006). Most seniors refers to have religion beliefs, being more prevalent among women ( $p=0,0000$ in 2000 e $p=0,0155$ in 2006) and among widowed $(p=0,0426)$. The greatest number of diseases and the worst status of health are related, principally, to elderly with no religion belief. The importance given to religion is higher among women, oldest old, and those who reported better health status. Despite the relevant given importance to religion in 2000 $(88,8 \%)$, it becomes even more relevant in $2006(92,7 \%)$. Most of elderly refers that religion gives strengthening $(89,3 \%)$, assistance to face difficulties $(87,2 \%)$, and meaning to life $(87,9 \%)$. Therefore, it is concluded that religion has becoming increasingly important for the elderly and has been identified as a source of social support and coping with the life's difficulties, and meaning to life facing health and aging process.
\end{abstract}

Key-words: Religion. Elderly. Aging. 


\section{LISTA DE QUADROS}

QUADRO 1: Questões do Estudo SABE relacionadas à religião nos anos 2000 e 2006. São Paulo, 2000 e 2006

QUADRO 2: Variáveis independentes, tipo, categoria e referência no questionário. Estudo SABE. São Paulo, 2000 e 2006 


\section{LISTA DE FIGURA}

FIGURA 1 - Participação de Católicos na População Brasileira 1872 a 2009 


\section{LISTA DE TABELAS}

Tabela 1 - Evolução da amostra de idosos do Estudo SABE no período de 2000 a 2006. São Paulo, 2000-2006.

Tabela 2 - Distribuição (\%) dos idosos segundo religião referida, sexo e idade. São Paulo, 2000 e 2006

Tabela 3 - Distribuição (\%) dos idosos segundo referência de crença religiosa e características sócio-demográficas. São Paulo, 2000 e 2006 .

Tabela 4 - Distribuição (\%) dos idosos segundo referência de crença religiosa e condições de saúde/doença. São Paulo, 2000 e 2006.

Tabela 5 - Distribuição (\%) dos idosos segundo importância atribuída à religião em sua vida e características sociodemográficas. São Paulo, 2000 e 2006

Tabela 6 - Distribuição (\%) dos idosos segundo importância atribuída à religião em sua vida e condições de saúde/doença. São Paulo, 2000 e 2006.

Tabela 7 - Distribuição (\%) dos idosos segundo frequência referida de participação nas atividades formais relacionadas ao credo religioso referido, sexo e idade. São Paulo, 2000 e 2006.

Tabela 8 - Distribuição (\%) dos idosos segundo fortalecimento e auxílio referidos advindos da religião, para o enfrentamento de dificuldades e sentido à vida fornecido pela mesma, sexo e idade. São Paulo, 2006

Tabela 9 - Distribuição (\%) dos idosos segundo referência de mudança de religião no período de 2000 a 2006. São Paulo, 2000/2006

Tabela 10- Distribuição (\%) dos idosos segundo mudança de credo religioso no período de 2000 a 2006, segundo sexo, idade, falecimento de filho ou cônjuge, presença de incapacidade e de sintomas depressivos. São Paulo, 2006 


\section{LISTA DE ANEXOS}

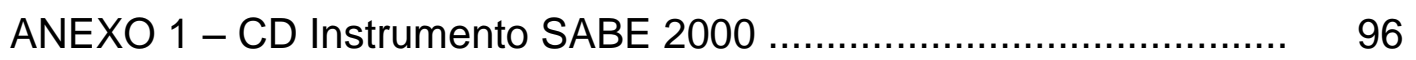

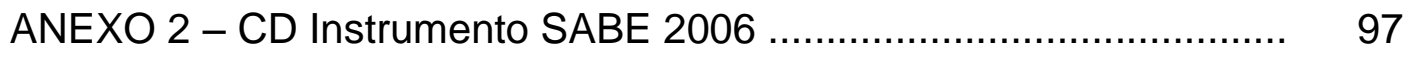

ANEXO 3 - Parecer do Comitê do CONEP (2000) ......................... 98

ANEXO 4 - Parecer do Comitê de Ética da Faculdade de Saúde Pública da Universidade de São Paulo (2006) ................ 99

ANEXO 5 - Termo de Consentimento Livre e Esclarecido do Estudo SABE 


\section{LISTA DE ABREVIATURAS E SIGLAS}

$\begin{array}{ll}\text { ABVD } & \text { Atividades Básicas da Vida Diária } \\ \text { AIVD } & \text { Atividades Instrumentais da Vida Diária } \\ \text { CERIS } & \text { Centro de Estatística Religiosa e Investigações Sociais } \\ \text { CONEP } & \text { Conselho Nacional de Ética em Pesquisa } \\ \text { FAPESP } & \text { Fundação de Amparo a Pesquisa do Estado de São Paulo } \\ \text { HIV } & \text { Vírus da Imunodeficiência Humana } \\ \text { IBGE } & \text { Instituto Brasileiro de Geografia e Estatística } \\ \text { ILPI } & \text { Instituição de Permanência para Idosos } \\ \text { MIF } & \text { Medida de Independência Funcional } \\ \text { MEEM } & \text { Mini-Exame do Estado Mental } \\ \text { OMS } & \text { Organização Mundial da Saúde } \\ \text { OPAS } & \text { Organização Pan-Americana de Saúde } \\ \text { PNAD } & \text { Pesquisa Nacional por Amostras de Domicílios } \\ \text { RR } & \text { Risco Relativo } \\ \text { SABE } & \text { Saúde, Bem-estar e Envelhecimento } \\ \text { Zarit } & \text { Avaliação da sobrecarga dos cuidadores }\end{array}$




\section{SUMÁRIO}

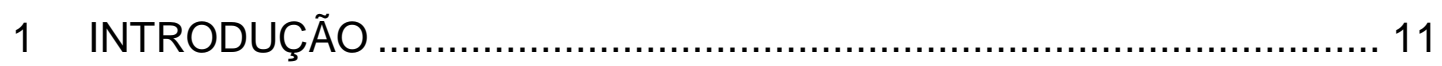

2 REVISÃO DE LITERATURA SOBRE RELIGIÃO ………................... 17

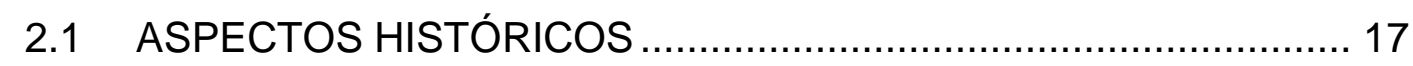

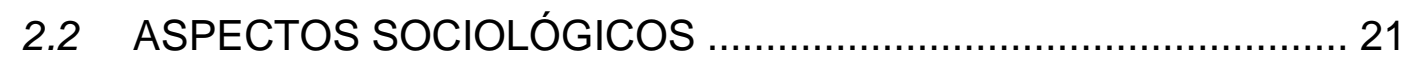

2.3 ASPECTOS ANTROPOLÓGICOS ….............................................. 26

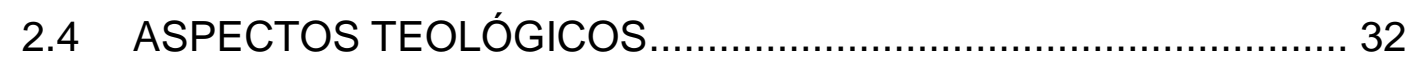

2.5 ASPECTOS PSICOLÓGICOS ....................................................... 34

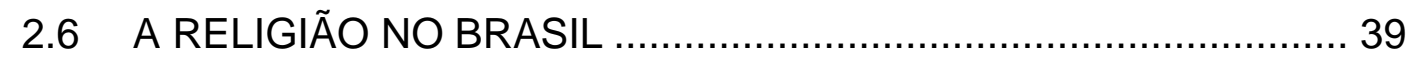

2.7 RELIGIÃO E ENVELHECIMENTO …....................................... 41

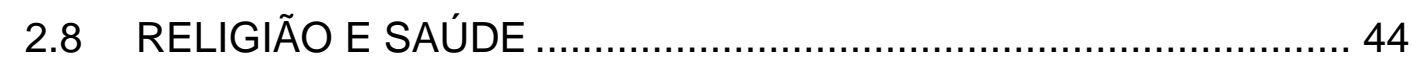

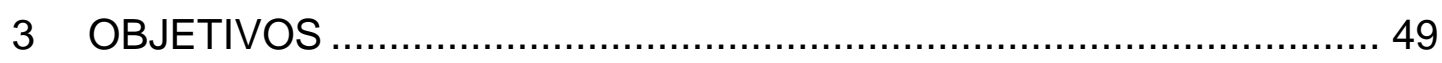

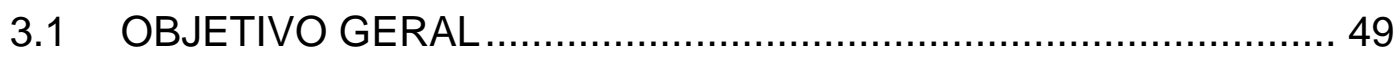

3.2 OBJETIVOS ESPECÍFICOS......................................................... 49

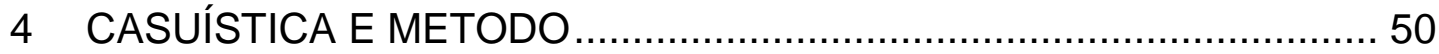

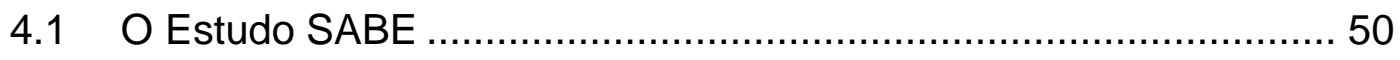

4.2 Análise dos dados do Estudo SABE ........................................... 55

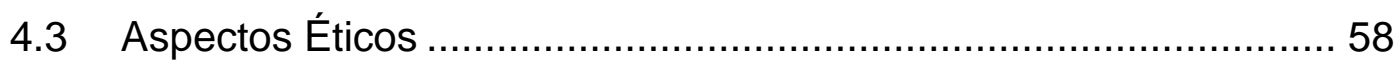

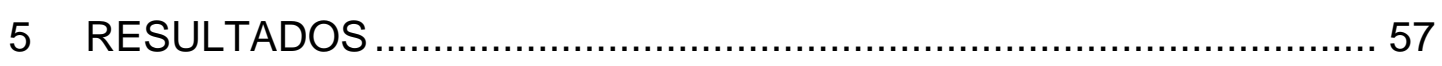

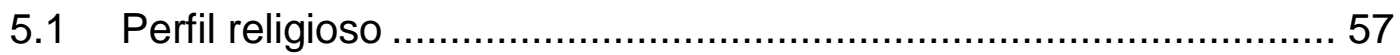

5.2 Religião referida e perfil sociodemográfico ................................... 59

5.3 Religião como fonte de força para o enfrentamento e compreensão das dificuldades da vida e como sentido para a vida ............................... 64

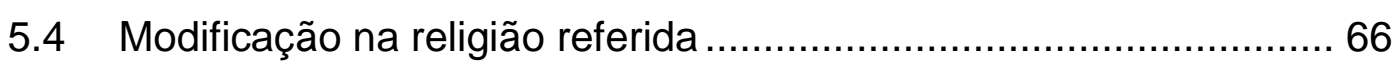

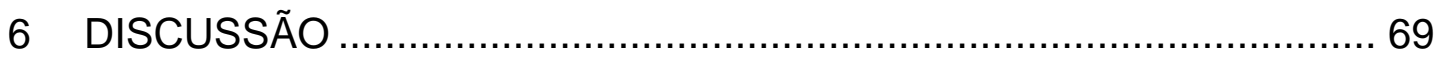

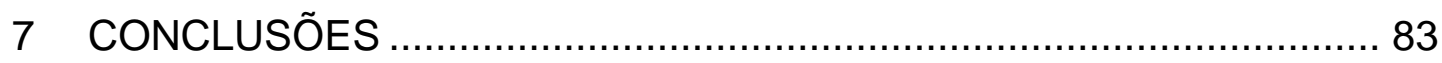

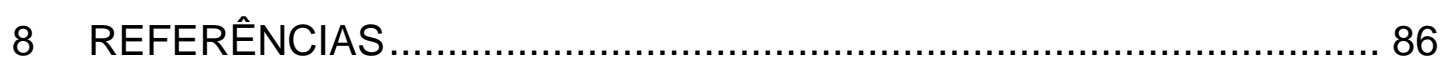

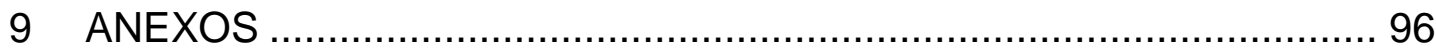


Apresentação 


\section{APRESENTAÇÃO}

Durante o curso de Graduação em Enfermagem sempre me interessei pelo idoso, principalmente pelas questões relacionadas aos aspectos afetivos e pelos meios de enfrentamento para lidar com a própria "velhice", com as doenças e incapacidades que eram adquiridas ao longo dos anos e, até mesmo, com a morte.

No último ano de graduação tive a oportunidade de trabalhar em uma Instituição de Longa Permanência para Idosos (ILPI), na qual ainda permaneci por mais seis meses após a formatura. Nesse período pude vivenciar diferentes experiências relacionadas ao processo de morrer e deparei-me com algumas dificuldades pessoais de enfrentamento dessas situações. Pude observar, diante de todas as "despedidas" que presenciei, que os idosos que referiram pertencer a alguma religião ou crer em uma força superior, costumavam deixar essa vida de forma mais serena, o mesmo ocorrendo com seus familiares que, diante de um momento que normalmente transmite tanta dor, monstravam-se mais "conformados" ou até mesmo mais "amparados" com a situação.

Posteriormente iniciei minhas atividades laborais no Hospital Universitário, onde a situação não se mostrava diferente. Pude constatar que a serenidade encontrada anteriormente entre os idosos com alguma crença também podia ser observada em adultos com doenças crônicas que não mais apresentavam um prognóstico favorável.

Dentre todos os casos que presenciei, um que me chamou bastante a atenção foi o de uma senhora, com diagnóstico de câncer de pulmão 
avançado, já sem possibilidades terapêuticas de cura. Ela era adepta a uma determinada religião e expressava uma fé fervorosa a Quem denominava de "meu Deus". Certo dia ao passar visita de rotina na Unidade de Internação, deparei-me com ela apresentando diversas queixas em relação ao seu estado de saúde. Dentro das minhas possibilidades, fui oferecendo opções para tentar amenizar suas principais queixas mas, apesar disso, não foi possível resolver todas... Nesse momento, ela me disse: “...Então segura na minha mão e reza?" Dentro da minha própria cabeça, segurei sua mão e rezei em silêncio. Ela estava acompanhada pela sua irmã, que também fez o mesmo gesto. Quando percebi, ela havia adormecido sem que tenha sido necessária a realização de qualquer procedimento específico aprendido durante minha vida acadêmica. Essa paciente recebeu alta algum tempo depois e continuou lutando por sua vida por mais um ano e três meses, tendo retornado depois para a mesma unidade, onde se despediu de nós, acompanhada por sua família e pelos membros de sua igreja.

A fé demonstrada por essa senhora, sua vontade de viver associada a sua crença e a forma que ela utilizava a religião para auxiliá-la no enfrentamento dos momentos tão difíceis, me motivaram a querer estudar e conhecer mais essa temática. Nesse período, fui apresentada ao Estudo SABE - Saúde, Bem estar e Envelhecimento, que abordava aspectos relacionados à religião e sua importância na vida das pessoas idosas.

Assim, iniciei esse estudo buscando investigar a existência ou não de associação entre religião referida e condições de vida e saúde entre os idosos residentes no Município de São Paulo e seu impacto na melhoria da qualidade de vida dos idosos. 
Introdução 


\section{INTRODUÇÃO}

A Organização Mundial da Saúde (OMS) define como idosa, nos países em desenvolvimento, a pessoa com idade igual ou superior a 60 anos e, nos países desenvolvidos, a partir dos 65 anos $^{1}$.

O envelhecimento populacional é, atualmente, um desafio tanto para países desenvolvidos quanto para os em desenvolvimento, porém, nos primeiros, o aumento dessa população ocorreu de forma gradativa e, por essa razão, mais organizada. Já nos em desenvolvimento, tal processo vem ocorrendo em uma velocidade sem precedentes, não permitindo a adequação das políticas locais, em tempo hábil, às novas demandas trazidas por tais transformações ${ }^{2,3}$.

Esse aumento na proporção de pessoas idosas está relacionado à queda nas taxas de fecundidade e mortalidade e, aumento da expectativa de vida, fatos esses relacionados às melhorias das condições de vida e saúde das pessoas e aos avanços científicos e tecnológicos ${ }^{4}$.

No Brasil, a proporção de idosos tem aumentado consideravelmente ao longo dos anos. De 2,6 milhões em 1950 (4,9\% da população) passou-se para 19,6 milhões em 2010 (10,2\%), estimando-se para 2050, uma proporção de $29,7 \%$ de idosos na população total ${ }^{5}$.

Comparado a outros países da América Latina, o Brasil apresenta uma transição demográfica avançada, acompanhada pela transição epidemiológica, que se traduz na mudança do perfil de morbi-mortalidade da 
população, em que é possível observar o aumento na incidência e prevalência de doenças e condições crônicas ${ }^{4}$. Esses países, no entanto, vêm passando por um período de transição no qual, além do enfrentamento das demandas decorrentes das doenças e condições crônicas em franco crescimento, ainda convivem com as doenças infecciosas e o recrudescimento de outras antes controladas (dengue, febre amarela, malária, etc. ${ }^{6}$. Isso representa um importante desafio para os gestores e as políticas públicas, pois se traduz em dupla carga de doenças que necessitam igualmente de atenção e intervenções.

O processo de envelhecimento também é acompanhado por modificações comportamentais Parte dos idosos tende a tornar-se mais introspectivo, fortalecendo valores pessoais, o "eu" interior. A participação em atividades religiosas tende a ser mais freqüentes e, por vezes, constitui sua única atividade. Muitos também recorrem à religião em busca de fortalecimento para o enfrentamento de momentos mais difíceis ${ }^{7,8}$.

Religião é difícil de ser definida em decorrência das múltiplas interpretações desenvolvidas por estudiosos, especialistas e religiosos. Não existe uma definição universalmente aceita, mas sim proposições de teorias relacionadas ao tema ${ }^{9,10}$.

No dicionário Oxford ${ }^{11}$ encontra-se como definição de religião a "crença na existência de um poder sobrenatural, criador e controlador do Universo, que deu ao homem uma natureza espiritual que continua a existir depois da morte do seu corpo". 
Para o filósofo Émile Durkheim, "religião é um sistema unificado de crenças e práticas relativas a coisas sagradas, isto é, coisas separadas e proibidas, crenças e práticas que unem numa única comunidade, chamada Igreja, todos os que a ela aderem".

Para James ${ }^{12}$ ela significa "sentimentos, atos e experiências de indivíduos em sua solidão, na medida em que se sintam relacionados com o que quer que possam considerar como divino, uma vez que a relação tanto pode ser moral, quanto física ou ritual”.

De modo geral, a religião pode ser compreendida como uma crença na existência de poder sobrenatural, que dá ao homem uma natureza espiritual contínua que permanece após sua morte. Está associada à adesão de crenças e práticas relacionadas a uma instituição religiosa organizada, com expressão de crenças e valores espirituais ${ }^{7,8,13,14}$.

Espiritualidade e religiosidade ainda são utilizadas como sinônimo, porém, apesar de serem conceitos que se relacionam, possuem definições diferentes. Enquanto a religiosidade está relacionada à realização de cultos e doutrinas compartilhados em grupos, a espiritualidade está voltada às questões sobre propósito e significado da vida, com crença em aspectos espiritualistas para justificar existência e significados ${ }^{15}$. Pode ser definida como "aquilo que permite que uma pessoa vivencie um sentido transcendente na vida. Trata-se de uma construção que envolve 'fé' e 'sentido" 16 .

Worthington, Kurusu e McCullough ${ }^{17}$ definem uma pessoa religiosa como aquela que tem crenças religiosas e que valoriza a religião como 
instituição, enquanto que a pessoa espiritualizada é aquela que acredita e tem devoção em uma força superior, sem necessariamente possuir crenças ou fazer parte de alguma instituição.

A crença pode ser entendida como uma convicção, uma certeza que a pessoa possui, uma visão da verdade. Valores são as manifestações das crenças dos indivíduos que podem ser observadas em seu comportamento adotado ou evitado ${ }^{8}$.

Para Elias apud Negreiros ${ }^{18}$, a adesão às crenças é mais forte em pessoas que têm uma vida mais imprevisível, mais ameaçadora. De certa forma, isso pode ser relacionando ao envelhecimento, pensando-se em uma fase de redimensionamento global frente a receios e dores provenientes s da fragilidade, vulnerabilidade e sofrimento por perdas ao longo da vida, além da sensação, às vezes angustiante, de aproximação da morte.

A fé é uma crença absoluta em alguma coisa, um meio de se relacionar consigo mesmo ou com uma força superior e se desenvolve a partir do crescimento espiritual ${ }^{7,8}$ e ela é a principal mantedora da religião 19.

A experiência religiosa teve papel fundamental no equilíbrio da humanidade, a partir do estabelecimento de valores e regras que orientaram o comportamento pessoal e as relações sociais em diferentes momentos da história. Possibilitou a manifestação de sentimentos, desejos e esperanças e motivou a busca do significado da existência ${ }^{20}$.

A busca de significado para a existência humana é considerada como condição essencial à vida. Encontrá-lo fornece às pessoas um propósito de 
vida, dá sentido às suas atitudes e dificuldades vivenciadas. Quando tal busca é infrutífera experimenta-se, muitas vezes, um sentimento de vazio e desespero ${ }^{9}$.

A proposta das instituições religiosas é responder questões relacionadas à existência do homem, portanto, para algumas pessoas, a religião pode ser considerada uma fonte de significado existencial, relacionada à transcendência, bem-estar, significado e desenvolvimento, aspectos estes considerados vitais na existência humana ${ }^{9}$.

Enquanto a religião fornece significado para a vida e para a morte, a espiritualidade reforça o significado das relações do indivíduo consigo mesmo, com um ser superior e com outras pessoas ${ }^{9}$. Ambas são tidas como importantes aliadas dos indivíduos que vivenciam situações de sofrimento ou doença.

Praticantes ativos de uma crença tanto podem adquirir comportamentos religiosos considerados benéficos, ou por outro lado, comportamentos de autopunição associados, geralmente, ao fanatismo religioso ou ao desenvolvimento de um otimismo irreal relativo à proteção ${ }^{13}$, 14.

Instrumentos que mensuram religiosidade no Brasil ainda são escassos e, além disso, não contemplam todas as religiões. Em geral, a avaliação da religiosidade tem sido baseada na afiliação, na prática religiosa ou na frequência aos cultos ${ }^{14}$.

Diante do exposto, o presente estudo visa, primordialmente, responder as seguintes questões: 
- Qual o perfil religioso dos idosos residentes no Município de São Paulo?

- Esse perfil se modifica com o avançar da idade ou na presença de alterações nas condições funcionas e/ou de saúde?

- Existe associação entre a religião e sua importância para a pessoa idosa com suas condições de vida e saúde?

Espera-se que os resultados obtidos com esse estudo possam vir a contribuir com a identificação da importância da religião para essa população, bem como no reconhecimento de seu papel nas intervenções de saúde e na busca da melhoria da qualidade de vida dos idosos. 
Revisão de Literatura 


\section{REVISÃO DE LITERATURA SOBRE RELIGIÃO}

\subsection{ASPECTOS HISTÓRICOS}

A ideia de religião surgiu em Roma, onde o termo religio se impôs a todas as línguas ${ }^{21}$. Religio é uma palavra latina, que originalmente significava um tipo de temor supersticioso, que evoluiu para consciência moral, implicando em sentimento religioso e culto aos deuses. Religião também pode significar a ligação de um adorador à divindade por meio de cerimônias, cultos e atos de devoção ${ }^{10}$.

Muitas são as explicações quanto ao surgimento das religiões. 0 homem, com o passar do tempo, logo percebeu as coisas ao seu redor como animadas, o que o levou a acreditar que eram possuídas por espíritos e que era necessário apaziguá-las. O antropólogo Edward Burnett Tylor (1832-1917) batizou essa forma de crença como animismo, compreendendoo como o primeiro estágio da evolução da religião, que foi seguido pelo politeísmo (crença em vários deuses, cada qual com sua especificidade) e, depois, pelo monoteísmo (crença em um único deus, o poder nas mãos de uma única pessoa ou pequeno grupo) ${ }^{10,22}$.

Com esta dinâmica de transcender-se, a humanidade entendeu como justificativa para sua criação a força de algo sobrenatural, superior e diferente ao que pudesse existir - denominando-a de diferentes formas (Deus, Tupã, Brahma, etc.) e com características comuns entre as etnias (imortal, poder incomparável, suprema complacência) -, criando a partir de 
então, diferentes experiências religiosas de acordo com sua cultura. Para descrever e comunicar-se com esta "Entidade Criadora", a humanidade criou as hierofanias (mitos, imagens, símbolos, danças, ritos, cantos, objetos e lugares sagrados, plantas, animais, cerimônias), ou seja, manifestações do sagrado no universo daqueles que o recebem, podendo ser tanto universais quanto locais ou históricas. A sistematização dessas figuras constituiu, portanto, a religião ${ }^{20,23}$.

Na Idade Média, entre os séculos XV e XVI ocorrem dois fenômenos importantes com relação à religião ${ }^{24}$ :

1. As viagens intercontinentais que permitem o contato com outros povos além-mar e com outras culturas, estabelecendo-se o sistema colonialista. Até então, havia o predomínio do cristianismo entre os europeus que possuíam poucas informações sobre o judaísmo, repulsa contra o islã e diversas informações sobre as religiões grega e romana, referências de literatura sobre o budismo e o hinduísmo;

2. Ruptura interna do cristianismo ocidental e a constituição do Protestantismo, surgindo como uma fratura religiosa, social e política, o que vale destacar a sua crítica a textos que fundavam posturas políticas do Papado e à datação e melhor textualidade das Escrituras Cristãs.

Entre os séculos XVIII e XIX ocorreram a Revolução Francesa e a Revolução Industrial, que trouxeram mudanças políticas, sociais e econômicas, assim como a retomada da expansão do colonialismo europeu. No século XIX predominavam as ideologias naturalista e positivista, nas 
quais a religião era pensada de forma progressiva e intransigente, classificando-se em níveis ultrapassáveis e denominados como naturalismo, politeísmo e monoteísmo. Como etapa final dessa escala evolucionista, previa-se o fim do monoteísmo por meio da secularização, o predomínio do ateísmo e a vitória do anti-clericalismo ${ }^{24}$.

A religião também pode ser vista por alguns pesquisadores como um produto de fatores sociais e psicológicos, reduzindo-se a apenas um elemento das condições sociais ou da vida espiritual do ser humano. Karl Marx, por exemplo, entendia a religião a partir dos "modos de produção", ou seja, da mesma maneira como se produzem os bens necessários à vida, pois estes formam o elemento elucidativo da sociedade. Assim, a economia explicaria a religião da mesma forma que explica a sociedade ${ }^{22,25}$. Mais recentemente observa-se o predomínio da ideia de que a religião tem sua própria estrutura, mesmo que ligada aos elementos social e psicológico ${ }^{22}$.

A diversidade de práticas e crenças religiosas fez com que algumas classificações das religiões fossem ensaiadas por estudiosos. No século XIX foi feita uma classificação de religiões primitivas ou inferiores e históricas ou superiores, mas que, por não ser convincente, foi superada. Outra tentativa de classificação foi a que categorizou as religiões como animistas, animatistas, monistas, panteístas e monoteístas, mas mostrou-se pouco clara na diferenciação entre tais categorias ${ }^{21}$. Gaarder, Hellern e Notaker ${ }^{22}$ dividiram as religiões em três categorias:

1. Religiões Primais: são as denominadas "religiões primitivas", e são encontradas em culturas ágrafas (povos tribais da África, Ásia, 
América do Norte e do Sul e Polinésia). Têm como principais características as crenças em diversas forças, deuses e espíritos (que controlam a vida cotidiana) e o culto aos antepassados. São religiões não literárias em que os mitos e os ritos de passagem desempenham papel importante. A comunidade religiosa não se separa da vida social e o sacerdócio é sinônimo de liderança política da tribo.

2. Religiões Nacionais: incluem diversas religiões históricas que não são mais praticadas (germânica, grega, egípcia e assírio-babilônica). Têm um sacerdócio permanente que se encarregava dos rituais. São adeptas ao politeísmo com uma mitologia bem desenvolvida. Seus deuses são os responsáveis pela escolha do líder da nação (monarquia sacra).

3. Religiões Mundiais: também conhecidas como religiões universais, visam validação mundial. Sua principal característica é o monoteísmo, a relação do homem com Deus e sua salvação tem grande importância, assim como a oração e a meditação. Podem ainda ser divididas em orientais e ocidentais, cada qual com sua origem, seus costumes, seus conceitos e suas crenças.

As diferentes religiões possuem características que lhes são peculiares e são pouco conhecidas por aqueles que não são adeptos a elas.

Definir religião e desvendar sua origem é tão complexoquanto determinar os elementos que a compõe. Podem ser considerados como principais $^{22}$ : 
a) o sujeito - Deus e o homem, pois a religião tem início no encontro do homem com o santo, o divino, o mundo transcendente,

b) o objeto - a aproximação do homem a Deus para adorá-lo, a partir de crenças e práticas individuais e sociais, tornando-se o "homo religiosus", que adora, louva e faz sacrifícios e o

c) "homo religiosus" - implica nesta relação com Deus, o sinal, a palavra, o mito, o rito, o sacrifício, que constituem um sistema de crenças e de práticas que leva à institucionalização da religião: lugares sagrados, textos, calendários, etc., e faz com que o homem adquira então uma consciência religiosa.

\subsection{ASPECTOS SOCIOLÓGICOS}

A sociologia é uma ciência que surgiu a partir das transformações sociopolíticas, culturais e econômicas que ocorreram na Europa nos séculos XVI e XVII. O longo processo histórico, que atinge seu ápice com a Modernidade no século XIX, trouxe transformações no campo religioso, como, por exemplo, a dissolução do feudalismo, marcando o gradual enfraquecimento do poder das igrejas cristãs. Paralelamente, ocorreu o processo de secularização da cultura e da sociedade, ou seja, um processo de reorganização do trabalho da religião em uma sociedade estruturalmente incapaz de responder às expectativas que ela mesma deve gerar para existir enquanto religião ${ }^{26}$.

Com o progresso, o conhecimento se propaga de forma rápida e o homem passa a perceber o mundo como um lugar passível de intervenções 
e a reconhecer que há possibilidade de atuação sobre o curso da história. Com isso, a visão de mundo do ponto de vista religioso, que antes apoiada no pensamento mítico, passa a ser iluminada pela ciência e ser explicada pela razão ${ }^{26}$.

As mudanças ocorridas no campo político e na economia tornam-se as bases de profundas alterações filosóficas. Na Modernidade surge a figura do "indivíduo", sujeito de direitos, dono do seu destino, dentro de uma concepção liberal de humanidade. A autoridade, como fonte do conhecimento, é criticada por pensadores da época. O indivíduo é proposto como base de interpretação do mundo pelo racionalismo cartesiano ${ }^{26}$.

Essas ideias tiveram grande impacto sobre a religião, pois o sentido religioso da vida e da sociedade deu lugar a uma visão racionalizada e secularizada, afirmando-se a liberdade de pensamento e a autonomia de consciência. O pensamento mítico-religioso passou progressivamente a ser substituído pelo pensamento racional ${ }^{26}$.

A sociologia pode, assim, ser compreendida como produto de um contexto político-ideológico e social que, ao mesmo tempo em que criava a Modernidade como realidade e como mito, ajudava a pensar, explicar e entender a nova sociedade em processo de reformulação ${ }^{26}$.

O entendimento da sociedade moderna exige o entendimento da religião que passou a ser estudada pelas ciências sociais. As referências religiosas foram substituídas pela história e as doutrinas e verdades religiosas passaram a ser questionadas. O conflito com a religião constituiuse torna-se parte inevitável da história, já que assim como o conhecimento, 
foi "controlado" pela religião. A vida social, econômica e política das comunidades do Ocidente eram administradas pelo cristianismo. A ciência passa, nesse momento, a submeter a religião a um "pente fino", não sendo mais necessário ser religioso para falar de religião ${ }^{26}$.

Para Durkheim ${ }^{19}$, a religião devia ser tratada como um fato social, sujeito às modificações que the conferem os processos sociais. Portanto, a sociologia buscava entender e explicar ritos e crenças em relação à forma de organização da sociedade. Tinha como objetos de estudo as práticas e crenças religiosas compreendidas enquanto fatos sociais explicáveis por outros fatos sociais ${ }^{26}$.

Uma das tarefas da sociologia da religião é reconhecer as funções sociais dos mitos, das doutrinas e dos dogmas religiosos, distribuídos em três dimensões ${ }^{26}$ :

1. a percepção do papel da religião nas diferentes sociedades e culturas;

2. a análise do sentido e do impacto da presença e da força das religiões durante a história humana;

3. a identificação das forças sociais que modelam as religiões por um lado, e o reconhecimento do papel das religiões na modificação dos processos sociais, por outro.

Para Marx, Weber e Durkheim, fundadores da sociologia da religião, a religião deve ser analisada para ser possível a compreensão da sociedade ${ }^{26}$. 
Segundo Marx (1818-1883) a religião é uma realidade histórica que depende, além das relações sociais, das relações econômicas em especial e também das condições naturais da vida e da consciência dos indivíduos. Para ele, a economia explica a religião, assim como explica a sociedade. A sociedade ideal é vista como a sociedade sem classes e as estruturas sociais seriam instauradas mediante a destruição das já vigentes, o que o levou a confrontar-se com a religião. Para ele, a religião é uma invenção da sociedade capitalista e um reflexo ilusório das relações de dominação de classe, de exploração. As ideias religiosas demonstrariam, justificariam e ocultariam a realidade da dominação. Marx defendia o desaparecimento da religião com a evolução do próprio processo histórico e do socialismo ${ }^{26,27,}$ 28

Durkheim (1858-1917), buscando definir sociologicamente a religião, encontrou nas formas mais rudimentares da religião totêmica das tribos australianas, dois fatos importantes ${ }^{26}$ :

1. as religiões são compostas por ritos, crenças e símbolos comuns a uma coletividade determinada;

2. a noção de "igreja”, intrínseca à religião.

Segundo ele, nas sociedades modernas a religião é importante por ser a responsável pela a união social e organização coletiva dos indivíduos. Ela nunca desaparecerá, pois sempre terá uma função social a realizar ${ }^{25}$.

Já para Weber (1864-1920) a religião é rica em significados culturais, capaz de interpretar a vida, construir uma identidade e inspirar processos históricos. Em relação à religião-mundo, dependendo do momento histórico, 
social e cultural, poderia haver diferentes formas de manifestações religiosas 26. Suas principais preocupações eram a sociedade moderna e o processo de racionalização que a compõe. Para identificá-lo, trabalhava comparando religiões de diferentes civilizações. Tinha como hipótese que a peculiaridade das religiões, que formam a base da cultura Ocidental, desempenhava papel importante na origem e desenvolvimento dessa racionalização. Para ele a religião tornava-se interessante à medida que era capaz de formar atitudes e disposições para aceitar ou rejeitar determinados estilos de vida ou para criar novos ${ }^{26,29}$.

Mesmo que de forma distinta, os três sociólogos reconheceram a importância da religião na vida do ser humano e sua eventual contribuição aos processos de mudança social.

Atualmente, muito se tem discutido sobre a secularização, póssecularização/dessecularização da religião, sua comercialização, sua perda de importância e retomada. Com a Modernidade, a religião passa por um período de decadência, no qual a ciência e a razão representam verdade absoluta. Para Weber, a secularização é a luta da modernidade cultural contra a religião, tendo como manifestação empírica a decadência desta como potência, sua separação do Estado e a perda de sua função de integração social $^{30}$.

No final do século $X X$, no entanto, observou-se uma expansão e a multiplicação considerável da religião, permitindo aos sociólogos a defesa do retorno do sagrado, a discussão da pós-secularização e o reencantamento do mundo, negando seu declínio e afirmando a importância da religião no 
mundo atual, tendo por base o surgimento de novos movimentos religiosos 30,31

Pós-secularização é um termo importante para reformulação das teorias sociológicas da religião e tem como propósito superar o ataque da modernidade ${ }^{30}$.

Oliveira ${ }^{31}$ destaca as transformações ocorridas nos movimentos religiosos, que passaram a apresentar preocupações voltadas para a paz, deveres humanos, meio-ambiente e bem-estar do indivíduo, dividindo opiniões quanto à manutenção de sua capacidade moralizadora.

Segundo Pierucci ${ }^{32}$ o ressurgimento religioso se reduziu ao âmbito individual, tendo perdido sua importância na vida social. Os novos movimentos religiosos vieram afirmar a secularização, pois reduziam a religião a mais um item de consumo. O pluralismo religioso é visto como algo mágico e místico a ser consumido pelo mercado e que não traz à religião valor ético e moral, o que acaba por desmoralizá-la.

Ao contrário de Pierucci ${ }^{30}$, Oliveira ${ }^{31}$ defende que apesar de todas as mudanças ocorridas no campo religioso e de sua "mercadorização", a religião ainda tem um papel moralizador influenciando a vida social e a ética da atualidade.

\subsection{ASPECTOS ANTROPOLÓGICOS}

Segundo o Dicionário Básico das Religiões ${ }^{21}$, Antropologia é o estudo do homem, de sua origem, evolução, sociabilidade, cultura, religião, o que é 
e o que faz, seu comportamento. Estuda a religião como forma de conduta, descrevendo as crenças e as práticas religiosas tais como são encontradas nas comunidades vivas.

Dentro de um contexto histórico, a antropologia da religião teve início em meados do século XIX, quando os primeiros estudiosos, liderado por Jean-Jacques Rousseau (1712-1778), foram influenciados pelo lluminismo (séculos XVII e XVIII), tendo como foco o "progresso da civilização humana". Esses estudiosos construíram a imagem do "bom selvagem", que inspirou a antropologia da religião durante séculos. Seu desenvolvimento teve como ponto de partida acreditar que os "selvagens" não possuíam religião. Essa conclusão foi obtida a partir das observações de viajantes europeus que procuravam, em outras culturas, apenas características de sua própria cultura, não reconhecendo o que não lhes fosse familiar ${ }^{25}$.

No final do século XIX e início do XX, mais acadêmicos europeus foram influenciados pelas ideias de uma evolução social dos seres humanos, e então, ao invés de negar a presença de tradições religiosas dentro de culturas não europeias, começaram a apreciá-las como raízes ou relíquias das culturas "mais" avançadas, da mesma forma que a europeia. Esse pensamento da evolução da humanidade está ligado a Charles Darwin (1809-1882), cujas ideias constituíram uma teoria social descrita pelo filósofo Herbert Spencer (1820-1882), baseada na evolução dos seres humanos a partir da idéia de "sobrevivência do mais forte". Acreditava ainda que as coisas animadas e inanimadas movem-se das formas mais simples às mais complexas. 
E.B. Tylor, conhecido com um dos pais da antropologia, foi influenciado pela teoria de Darwin e denominou essa forma de crença de animismo. Segundo ele, o desenvolvimento religioso caminhou paralelamente ao avanço da humanidade, indo em direção ao politeísmo e posteriormente, ao monoteísmo ${ }^{22,25}$.

No século $X X$, os pensamentos passaram a se voltar para a religião como projeção de alguma particularidade da natureza, tendo o funcionalismo (filosofia sociológica que tenta explicar as instituições sociais como meios de satisfazer necessidades biológicas individuais) como uma das principais abordagens. Promovido pelo sociólogo Émile Durkheim (1858-1917), que rejeitava as interpretações biologicistas e psicologicistas do fenômeno social; considerava os fatos sociais como características e os determinantes sociais como distintivos. Compreendia a religião como uma afirmação simbólica da sociedade; interessava-se pelo estudo dos grupos e objetivava investigar as funções da religião ${ }^{25}$.

Outro importante expoente do funcionalismo foi o antropólogo Bronislaw Kasper Malinowski (1884-1961), que promoveu uma visão emocionalista da religião, acreditando que todo ser humano necessita de algum tipo de crença. Desenvolveu importante trabalho sobre a magia na antropologia, distinguindo, na sociedade, a parte sagrada da profana. Magia e religião pertencem à parte sagrada e a ciência, à profana. Ambas tinham como função explicar e controlar o mundo cabendo à religião a responsabilidade pela promoção dos eventos importantes da vida, os ritos de passagem, o valor e o significado ${ }^{25}$. É interessante observar como a 
realidade sagrada provocava uma divisão social e real. O sagrado era compreendido como especial, significante e orientador da convivência humana, obrigando a sociedade a manter comemorações e ações de respeito. O sagrado aparecia como algo desconhecido, diferente do normal, porém ao mesmo tempo, real e fundamental. Esta realidade caminha em paralelo a outra sociedade e outra realidade não interpretada de forma simbólica ou transcendente, denominada de mundo profano. Este está relacionado ao mundo cotidiano, àquilo que não tem ligação com um templo ${ }^{33}$

Após a Segunda Guerra Mundial, ocorreram mudanças na antropologia e na ciência da religião. Edward Evans-Pritchard (1902-1973), um importante antropólogo do século $X X$, trouxe uma nova maneira de abordar a religião. Colocava em questão a dificuldade que os estudiosos tinham de penetrar no universo mental da cultura estrangeira e a dificuldade de tornar aquele universo compreensível aos outros membros da própria cultura $^{33}$.

Para Goldman ${ }^{34}$, a antropologia tem por objetivo pensar a diferença intercultural e explicar a razão ou a falta desta nos outros. Esse trabalho de inspecionar ou excluir diferenças traz como consequência a valorização dessa diferença, utilizada pela antropologia como ponto de apoio para motivar o pensamento e não como algo simples a ser explicado.

Sob uma ótica cosmocêntrica, destaque deve ser dado às considerações de Platão, Aristóteles e Plotino. Platão acreditava que o homem era essencialmente alma e, consequentemente, imortal tendo como 
principal problema libertar a alma da prisão do corpo. Para Aristóteles, o homem era constituído de alma e corpo, sendo a alma responsável pela forma e apesar de possuir superioridade em relação ao corpo, não teria condições de escapar da corrupção e da morte. Plotino também defendia que o indivíduo era composto por corpo e alma, sendo o conhecimento intelectual exclusividade desta última, enquanto todas as outras funções do conhecimento eram realizações do corpo a partir de informações fornecidas pela alma ${ }^{27}$.

Com o cristianismo, surgiu uma nova reflexão antropológica, a teocêntrica, na qual o desenvolvimento da vida humana deixa de estar associado à natureza e ao cosmos, para se voltar à história das relações entre Deus e a Humanidade.

Entre as diversas abordagens antropológicas traçadas pelos pesquisadores cristãos, duas merecem destaque: a de Santo Agostinho e a de São Tomás.

Santo Agostinho tem toda a sua obra centrada em Deus e no homem, com ênfase neste último. Trouxe à tona revelações cristãs, noções e problemas que os gregos ainda não haviam observado, tais como o pecado, o mal, a liberdade, a pessoa, etc. Inspira-se na abordagem antropológica desenvolvida por Platão, na qual o homem é composto de corpo e alma, sendo esta detentora de importante superioridade e o conhecimento intelectivo com autonomia em qualquer contribuição do corpo ${ }^{27}$.

São Tomás dividia-se entre as abordagens antropológicas de Platão e de Aristóteles, pois acreditava que o primeiro fornecia uma solução 
filosoficamente fraca, porém substancialmente de acordo com a fé, enquanto o segundo trazia um conceito de homem mais sólido, mas não tão compatível com a visão cristã. Por essa razão, criou uma nova abordagem antropológica, tendo como características a dicotomia corpo e alma. A alma é autônoma e imortal permitindo a participação do corpo em sua existência ${ }^{27}$.

Com o início da modernidade, a pesquisa antropológica abandona a imposição cosmocêntrica dos filósofos gregos e a imposição teocêntrica dos cristãos e parte para a linha antropocêntrica, sendo o homem ponto de partida e em torno do qual se volta à atenção da pesquisa filosófica ${ }^{27}$.

Atualmente, a maioria dos antropólogos vem estudando a experiência religiosa individual com uma abordagem holística. A religião é sempre vista em relação a outras instituições e constructos sociais, nunca autonomamente ${ }^{25}$.

Para alguns antropólogos, o homem é religioso não só de fato e de direito, o que, para Mondin ${ }^{27}$ relaciona-se à finitude, ao acaso, à dependência (em relação à lei moral). Quando o ser humano toma conhecimento dessas características, ele se abre naturalmente a um Ser superior e entra em contato com Ele por meio de uma oração, da adoração, do sacrifício, assumindo então uma dimensão religiosa precisa, estruturada e ordenada ${ }^{27}$. 


\subsection{ASPECTOS TEOLÓGICOS}

A palavra Teologia vem do mundo grego, mais concretamente da filosofia, e significa um discurso racional sobre Deus, uma explicação da razão, não do mito nem da poesia ${ }^{21}$. É um modo de conhecimento da mesma realidade que a razão explora com o auxílio de um método científico. A ciência muda os seus métodos e alcança novos resultados, mas o seu objetivo permanece o mesmo ${ }^{35}$.

Na antiguidade cristã, o pensamento de fé dos teólogos, nos primeiros concílios consolidava-se frente à superação das religiões misteriosas, pela desmistificação de que Jesus não era somente uma pessoa do passado, mas um só tempo em relação ao presente e futuro. Na Idade Média, os religiosos buscavam apoio na fé e na razão, tendo destaque Anselmo da Cantuária, teólogo considerado um dos iniciadores da tradição escolástica, que buscava dentro do sistema global da fé, razões necessárias para cada uma das verdades de fé, além de argumentos para provar a existência de Deus e a necessidade de Sua encarnação para a salvação do homem. Ao longo dos anos, a relação entre fé e saber passa a ser um problema teológico. Enquanto Anselmo se esforçava para compreendê-la pela inteligência, os teólogos da época acreditavam que como os mistérios da fé não eram compreensíveis ao homem, deveriam ser evidenciados por testemunhos externos, como milagres e profecias, surgindo assim a teologia como ciência ${ }^{36}$.

Na Idade Moderna, com a secularização, a teologia passou a ser questionada qualificando a Modernidade como contrária a Deus e às 
verdades imutáveis da fé. Porém, a partir do amadurecimento dado pelos movimentos de ação católica e reflexões inovadoras (tanto no campo católico como no evangélico), e com o Concílio do Vaticano II, a teologia revelou uma atitude mais positiva diante da Modernidade, permitindo uma reestruturação na reflexão teológica ${ }^{37}$.

Do ponto de vista protestante, a teologia desenvolveu-se como ciência da linguagem, da história, da religião e também como ética, além de sua importância para o ecumenismo ${ }^{36}$.

Desde a Modernidade, com a secularização, a teologia vem perdendo campo para as ciências da religião e, atualmente, muitas são as discussões, sobre a rivalidade existente entre elas. Uma das grandes dificuldades é estabelecer a diferenciação entre esses dois campos do conhecimento. A ciência da religião afirma não ser teológica e usa como método de estudo a observação à distância das instituições religiosas e a comparação das mesmas sem atribuição de valor. A teologia estuda a religião do ponto de vista interno, explicando a verdadeira fé perante interpelações, julgamento normativo de fenômenos religiosos empíricos e tarefas práticas de formação para membros do clero. Apesar dessas distinções, ambas apresentam alguns pontos de ligação, diante dos quais cada uma, à sua maneira, utiliza o que a outra possui de melhor em seu próprio benefício ${ }^{38}$.

Soares ${ }^{39}$ aborda a questão da "rivalidade" entre as duas ciências, questionando a necessidade do ensino de teologia frente à ciência da religião e comentando a importância de uma colaboração mútua entre as duas, pois servem como demarcadoras úteis ao avanço da reflexão. 
Enquanto a ciência da religião oferece um conhecimento intransigente, que possibilita ao teólogo um confronto com a realidade e conhecimento capaz de favorecer suas reflexões sobre fé, revelação e dogma, a teologia revela a tradição religiosa e funciona como delimitadora do progresso do conhecimento científico sobre determinada religião, já que focada em sua crença, testa a coerência entre essa tradição sem sofrer influência de comentários capciosos e dificuldades interpretativas.

Soares ${ }^{39}$ discute ainda, a necessidade de uma nova teologia, universal, acessível de modo natural a qualquer pessoa, independente de sua crença. Dierken ${ }^{38}$ afirma que uma "boa" teologia deve ter a pretensão de divulgar, de modo adequado, a religião que representa para seus fiéis, pessoas de outras convicções ou não-crentes, mesmo que ela tenha como objetivo o fortalecimento da transformação de valores em interesse próprio.

\subsection{ASPECTOS PSICOLÓGICOS}

A Psicologia como ciência refere-se ao estudo do comportamento humano, ou seja, do conjunto das ações objetivas e subjetivas do ser humano ${ }^{40}$.

A Psicologia da Religião objetiva estudar e analisar a estrutura psíquica da experiência religiosa do ser humano, tanto de forma consciente como inconsciente, assim como no sentido pessoal e sociocultural ${ }^{41}$. Ela está relacionada ao estudo do comportamento religioso, voltado a um elemento superior (denominado Deus na cultura ocidental, porém pode receber diversas outras denominações), podendo este ser de rejeição ou 
aceitação ${ }^{42}$. O objetivo geral da Psicologia da Religião é relacionar comportamentos religiosos, explorar a diferença entre os significados religiosos, entender os diferentes comportamentos religiosos (que dividem o mundo entre elementos sagrados e profanos) com relação a outros fenômenos humanos ${ }^{43}$.

Dentro do mundo anglo-saxão, a Psicologia da Religião foi fundada pelo psicólogo e educador Granville Stanley Hall, que iniciou seus estudos com a teologia e a filosofia, partindo posteriormente para a Psicologia ${ }^{44}$. Já no Brasil, ela teve influência europeia, quando na década de 1950, foi confiado ao psicólogo holandês Theo van Kolck a direção de um departamento de Psicologia da Religião na Pontifícia Universidade Católica de São Paulo, fortemente influenciada pela Universidade Católica de Lovaina (Leuven) ${ }^{42}$. Na mesma época, foi criada em São Paulo a Associação de Psicologia Religiosa, reunindo sacerdotes, médicos e antropólogos.

No Rio de Janeiro, em meados da década de 50, o sacerdote húngaro, Antonius Benkö, iniciou as primeiras pesquisas sobre a Psicologia da Religião, a partir do artigo "Um ensaio de exame psicológico dos seminaristas”, em $1956^{42}$.

O interesse em se pesquisar religião pela psicologia teve início a partir do momento que pesquisadores psicólogos, como Freud, perceberam que a religião possuía um abastado campo de estudos relacionados a processos psicológicos importantes, como assuntos voltados à culpa, ansiedade, crenças e inter-relações entre variáveis cognitivas e emocionais, além de um 
vasto campo voltado para o estudo da interação social e processos grupais $^{44}$.

Paiva et al ${ }^{42}$ realizou um estudo a respeito de publicações em relação à Psicologia da Religião no período de 1956 a 2005, sendo observado um aumento gradativo no número de pesquisas, tendo como principais temas saúde, experiência religiosa, vocação religiosa/sacerdotal, identidade religiosa e relações entre psicologia e religião, que têm se mostrado cada vez mais frequentes.

Foram identificadas diferentes dimensões da vida religiosa, como dimensões ideológicas, ritualísticas, intelectuais, tolerância-preconceito e tipos de experiência religiosa (revelatória, confirmatória, salvacionista, etc). Dalgalarrondo ${ }^{44}$ cita Meadow e Kahoe ${ }^{45}$, que dividem essas dimensões em três áreas:

a) origens, funções, desenvolvimento do sentimento religioso e estados de desenvolvimento religioso;

b) experiências religiosas características: oração, conversão, cura pela fé, espiritualidade e experiências de êxtase;

c) variáveis psicológicas no aspecto religioso: crença e fé, consciência e sentimento de culpa, esperança e vontade religiosa.

A Psicologia da Religião norte-americana tem seus aspectos voltados principalmente para a "experiência", muito mais do que para as intervenções psicológicas e psicossociais. Além do que, do ponto de vista dos pesquisadores, as atenções concentram-se no "indivíduo". Maior importância é dada à dimensão afetiva da experiência religiosa, sendo todos esses 
aspectos herdados provavelmente por William James, filósofo e psicólogo que escreveu livros influentes sobre a ciência da psicologia, retratando assuntos voltados para a psicologia da experiência religiosa e que acredita que a religiosidade é a maior das forças psicológicas do homem ${ }^{44,41}$.

Para Valle ${ }^{41}$, a experiência religiosa reflete com emoção aquilo que é vivenciado e não ensinado ou aprendido, ou seja, a Psicologia da Religião não se preocupa com o teor filosófico ou teológico do fato religioso, mas com a estrutura psicológica que está em volta das vivências e experiências religiosas.

Segundo Rodrigues ${ }^{40}$, existem algumas correntes de compreensão da Psicologia da Religião que se distinguem entre si pela percepção que fazem da religiosidade para o ser humano, como por exemplo, a corrente sociobiológica, que considera que tudo o que é útil à espécie permanece e desenvolve-se. A religião é o elemento instintivo de utilidade para a perpetuação da espécie.

A corrente psicobiológica fundamenta-se na instintividade natural do ser humano e descreve a religião baseado em instintos voltados para a atitude (medo, curiosidade e sujeição) e em instintos emocionais (admiração, reverência e fascínio) ${ }^{40}$.

Dalgalarrondo ${ }^{44}$ aponta como um dos desenvolvimentos da pesquisa empírica da psicologia da religião as "formulações binárias" em relação aos tipos de religião e religiosidade, as quais se opõem entre uma religião mais elevada, simbólica, abstrata e humanista com outra sectária, concreta e doutrinária. Nessa contraposição, as que merecem maior destaque são a 
religiosidade intrínseca e a extrínseca, estando a primeira relacionada a uma boa forma de religiosidade, madura, simbólica, intelectualizada e internalizada, enquanto a segunda está voltada para uma forma ruim e imatura de religiosidade, que seria extrínseca, mágica, ritualística.

Gordon Allport ${ }^{46}$, psicólogo norte-americano, também se preocupa com aspectos contraditórios da religião. Ele acredita que os sentimentos religiosos de grande parte das pessoas são imaturos, que estas adotam uma divindade para auxiliá-las em seus interesses imediatos, sendo a religião utilizada apenas como instrumento de auto-estima. Este tipo de religiosidade, portanto, apresenta um valor "extrínseco", pois o indivíduo acredita que sendo religioso, isso auxiliaria seus objetivos imediatos. Opostamente a esta religiosidade, há um sentimento religioso que oferece ao indivíduo uma solução compreensiva para os problemas encontrados em sua vida, em que a busca religiosa é vista como um fim em si mesmo, sendo desejável por si só. Dessa maneira, a religião seria vista como integradora, motivacional e compreensiva, tendo, portanto, uma valor intrínseco ao indivíduo. Há, no entanto, diferentes formas de se encontrar na religiosidade um sentido pleno, não sendo sua forma intrínseca o único caminho ${ }^{44}$.

Observa-se, portanto, que ao longo dos anos, as pesquisas relacionadas à psicologia da religião vêm tendo avanços importantes e, segundo Farris ${ }^{47}$, a psicologia da religião também tem participando de diversos tipos de diálogo trans-disciplinar, com a teologia e a ética, assim como de que forma pessoas e grupos usam a religiosidade a fim de resolver problemas e lidar com crises e traumas. Ressalta, ainda, que a psicologia 
traz apenas um "sentido" da religião dentro do contexto humano, porém, ao mesmo tempo, ela contribui para o entendimento do lugar, da função e do sentido da religião na vida e na personalidade humana.

\subsection{A RELIGIÃO NO BRASIL}

O Brasil, um país permeado pela diversidade religiosa, está em $78^{\circ}$ no ranking global sobre religiosidade ativa, realizada em 156 países. Estimase que $50,0 \%$ dos brasileiros frequentam cultos religiosos de qualquer credo 48.

Além das religiões, seitas e crenças antigas já embutidas em nossa cultura, observa-se, atualmente, o surgimento de novas crenças e a transição de adeptos entre as religiões, prática esta cada vez mais frequente.

Antigamente, a religiosidade representava uma tradição cultural. A adoção de crenças, valores e princípios religiosos vigentes na família eram vistos como parte do processo de socialização dos indivíduos e, por essa razão, sua escolha estava pautada nas tradições familiares. Hoje em dia, reinterpretada pela modernidade, tem sua adesão voltada para as situações e necessidades individuais, o que permite uma diversidade de escolha no vasto campo de opções das religiões, dissociando-a das obrigatoriedades tradicionais. 
Dados do censo de 2000 mostram a importância da religião em nosso país ${ }^{1}$. Numa amostra de cerca de 20 milhões de pessoas, 92,5\% referiram ter uma religião e 7,3\% se autorreferiram como "sem religião". Observou-se ainda uma grande variedade religiosa, com predominância do grupo de católicos $(73,8 \%)$, evangélicos $(15,4 \%)^{2}$, espíritas $(1,4 \%)$, afro-brasileiros $(0,3 \%)$, judeus $(0,1 \%)$, budistas $(0,2 \%)$, orientais $(0,1 \%)$, muçulmanos $(0,01 \%)$ e esotéricos $(0,04 \%)^{1,49}$.

Apesar da maior parte da população brasileira se declarar católica, a taxa de adeptos vem caindo ao longo dos anos. Até a década de 1960, havia uma hegemonia católica na sociedade brasileira. Nos anos seguintes, observa-se o aumento do pluralismo e a abertura a diferentes tradições religiosas, principalmente nas camadas mais populares ${ }^{50,51}$.

Figura 1 - Participação de Católicos na População Brasileira - 1872

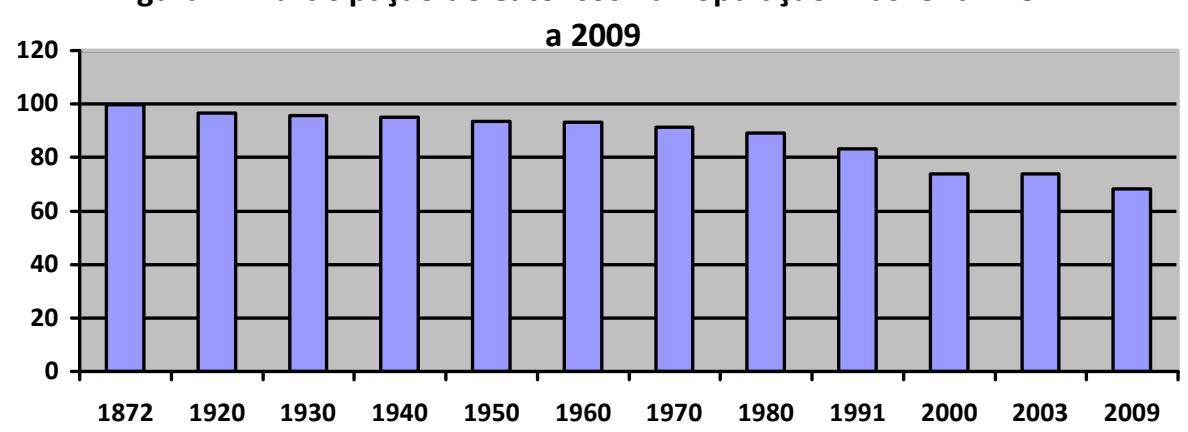

Fonte: Centro de Pesquisas Sociais/ Fundação Getúlio Vargas a partir do processamento de dados publicados e microdados do IBGE.

\footnotetext{
${ }^{1}$ Dados do censo 2010 sobre religião não foram disponibilizados até a data de publicação desta dissertação

${ }^{2}$ Não há especificação na publicação se evangélicos e protestantes foram colocados no mesmo grupo [Nota do Autor]
} 
Dados do Centro de Pesquisas Sociais e da Pesquisa de Orçamentos Familiares de 2009 mostram o crescimento dos evangélicos chegando a 20,2\% e um aumento no número de adeptos às religiões alternativas, que passaram de 2,6\% em 2000 para 4,62\% em 2003, mantendo-se em $2009{ }^{48}$.

Essa diversificação está relacionada tanto à circulação das pessoas por diversas instituições religiosas, quanto às mudanças ocorridas nas práticas e nas crenças ao longo do tempo. A transição entre religiões, nos dias atuais, é facilitada pela maior aceitação da sociedade, mesmo pelos indivíduos mais velhos, o que favorece a diversificação das crenças no país 52.

\subsection{RELIGIÃO E ENVELHECIMENTO}

Ultimamente observa-se grande interesse em se pesquisar a religião retratando aspectos voltados para a saúde física, mental e qualidade de vida.

Acredita-se que pode haver uma associação da religião com a amenização do sofrimento físico e psíquico, com o aumento do bem-estar e a redução dos níveis de depressão e angústia, além de trazer explicações relacionadas ao sentido da existência e da morte ${ }^{53}$.

De forma geral, estudos têm demonstrado a importância da religião sob diferentes ângulos. Atualmente, um dos aspectos retratados na literatura é a relação entre religião e envelhecimento, considerando a representação que aquela pode ter neste momento da vida. 
Segundo Santana ${ }^{9}$, as crenças religiosas desempenham papel importante na sociedade na união das pessoas ao redor de um místico comum, transmitido através de gerações, auxiliando os indivíduos a encontrar senso de identidade e pertencimento.

As práticas e as crenças religiosas podem influenciar a saúde mental, ter impacto no bem-estar emocional e, consequentemente, propiciar recursos e comportamentos de enfrentamento, o que pode ajudar as pessoas na adaptação e na superação de eventos estressores, resultando em bem-estar, satisfação com a vida, esperança, aumento do apoio social e diminuição da sensação de solidão ${ }^{54}$.

Acredita-se que, com o início da meia idade, as pessoas tendam a dar menos importância a situações sociais externas e comecem a valorizar mais os processos internos, fazendo reflexões de natureza retrospectiva, em busca de um significado ou propósito para a vida, além de considerações sobre finitude da existência, abrindo, dessa maneira, portas para as questões religiosas ${ }^{55}$.

Em relação aos idosos, a religião é reconhecida como fonte de apoio, pois os ajuda a encontrar um sentido em situações negativas, a aceitar a si mesmos e aos outros e a perdoar, a se aproximar de outros idosos ou religiosos que podem oferecer apoio emocional e ajudá-los a encontrar sentido no sofrimento ${ }^{56}$. Entre os idosos praticantes, observa-se maior autoconfiança, serenidade, felicidade, capacidade de adaptação, enfrentamento e sentimento de inclusão social ${ }^{8}$.

Há três dimensões envolvidas na religiosidade ${ }^{57}$ : 
1. As atividades religiosas organizacionais, que envolvem participação de atividades em grupos, como leitura da bíblia e atendimento em igrejas;

2. As atividades religiosas não organizacionais, que consistem em atividades mais individuais, como meditação, leitura da bíblia, ouvir/assistir programas religiosos no rádio/TV,

3. A religiosidade intrínseca ou subjetiva, que refletem a religião como motivação primária para a vida das pessoas.

A religião pode se apresentar de duas maneiras: a intrínseca e a extrínseca. A primeira relaciona-se à pessoa que tem a religião como parte da sua vida diária, internalizando suas crenças e colocando outras necessidades em segundo plano e, que, quando possível, procura harmonizá-las. Já na segunda, a religião está relacionada apenas a satisfação das necessidades espirituais sendo utilizada de forma mais superficial, para obtenção de outros interesses como segurança, consolo, sociabilidade e distração ${ }^{53,54,55}$.

Para os idosos, a religião serve para diferentes propósitos na vida, como satisfazer uma necessidade espiritual ou pessoal ou ser um acontecimento social que lhes permite afirmar-se como indivíduo ${ }^{8}$.

Para Koening 58, o envelhecimento bem-sucedido - além da manutenção do vigor físico e da capacidade de manter autonomia e independência - está relacionado ao sentimento de dever cumprido, de satisfação, de amar e ser amado. Pode, no entanto, ser afetado pela 
diminuição da renda salarial, presença de doenças e incapacidades e, conseqüente, aumento no uso de medicamentos, além da perda de papéis.

O auxílio para as respostas humanas e controle das perdas ocorridas nessa fase, independente da cultura, é, muitas vezes, encontrados na religião, que proporciona conforto, esperança e direcionamento ${ }^{58}$.

\subsection{RELIGIÃO E SAÚDE}

Segundo estudos antropológicos, desde a antiguidade, devido à ignorância sobre as enfermidades, o poder da cura era divinizado. Acreditava-se que eram os deuses os responsáveis por causar as doenças e também por curá-las. Os sacerdotes, mediadores entre os homens e os deuses, eram os únicos que podiam interferir no processo saúde-doença. Esse pensamento permaneceu até o período hipocrático, quando houve o início da dissociação entre a arte da cura e os preceitos místicos e sacerdotais, por meio da utilização do método indutivo da inspeção e observação $^{59}$.

Do século $\mathrm{V}$ ao XIII, o monopólio moral, intelectual e financeiro pertencia à igreja, e os conhecimentos relacionados à saúde eram restritos ao clero e desvinculados da ciência, fatos que ocasionaram a volta do misticismo e do culto a Cristo, em que Deus passa a ser não só o Senhor da vida e da morte, mas também da saúde e da doença. Assim, a saúde era compreendida como premiação à obediência divina e a doença, o castigo. Quando pessoas obedientes a Deus eram acometidas por doenças, atribuíase a responsabilidade ao diabo, o antideus. Após o século XIII, com a queda 
do poder da igreja surge o pensamento científico, que obteve grande expansão com a Revolução Industrial ${ }^{59}$.

Atualmente, a interface entre a religiosidade e a saúde tem sido trazida novamente à tona. Ao longo da última década, o paradigma religioso e espiritual de cura tem tido sua importância aumentada na medicina ocidental. A atenção aos aspectos religiosos e espirituais torna-se cada vez mais importante na assistência à saúde. Resultados que comprovam o suporte terapêutico fornecido e os desfechos positivos obtidos têm feito com que a medicina se curve cada vez mais sobre a grandeza do assunto. Para Pessini ${ }^{60}$, a questão sobre religiosidade/espiritualidade e saúde deve girar em torno de "um viver saudável e feliz, tendo como parceiro o conhecimento científico".

As crenças religiosas podem auxiliar ou prejudicar a busca dos cuidados de saúde quando as pessoas atribuem a Deus todo o controle de sua doença. Koening, McCullough e Larson ${ }^{54}$ estudaram os efeitos positivos e negativos que a religião pode causar na saúde.

Os efeitos positivos parecem estar associados a sermões realizados por líderes religiosos gerando bem-estar, felicidade, propósito de vida, comprometimento matrimonial, familiar e com outras pessoas, além de alegria, paz e confiança. Quanto aos efeitos negativos, a substituição do tratamento médico pelo uso da religião, ou seja, o desenvolvimento de um otimismo irrealista relativo à proteção pode retardar a busca por tratamento adequado quando a enfermidade já está instalada ${ }^{54}$. 
Guimarães e Avezum ${ }^{15}$, ao avaliarem o impacto da espiritualidade na saúde física, observaram a redução de níveis estressores, depressão e mortalidade em indivíduos participantes de práticas religiosas, estando esta última associada à aquisição de hábitos saudáveis, como interrupção do tabagismo, atividade física regular, suporte social e manutenção do estado matrimonial. Verificaram ainda a importância da prece em pacientes cardiopatas.

Em revisão de literatura sobre a oração intercessória, aquela que visa o bem do próximo e não só o do próprio indivíduo, realizada por Rosa, Silva e Silva ${ }^{61}$ e Tosta ${ }^{62}$, embora tenham encontrado resultados, muitas vezes significativos, em relação aos efeitos benéficos trazidos pela prece, perceberam algumas falhas metodológicas, como falta de escalas padronizadas e validadas e padronização da intensidade e duração da oração, além da veracidade da realização das mesmas à distância e da influência que a prece realizada por amigos e/ou familiares poderia ter.

Segundo Pessini ${ }^{60}$, ao se estudar os componentes individuais da experiência religiosa, cientistas descobriram associação entre meditação e mudanças na atividade cerebral, fortalecimento da resposta imunológica, diminuição dos batimentos cardíacos e da pressão arterial e consequente redução do estresse.

Pargament e cols ${ }^{63}$ apud Faria e Seidl ${ }^{13}$ verificaram que as pessoas podem assumir diferentes posições para a solução de seus problemas. Por um lado, o indivíduo assumiria a responsabilidade na condução de sua vida a partir da liberdade concedida por Deus (self-directing); de outro, transferiria 
essa responsabilidade a Deus, esperando que Ele resolvesse seus problemas (defering) e, por fim, essa responsabilidade pode ser dividida entre Deus e o indivíduo, ambos participando na solução do problema. Segundo os autores, a utilização da religião no enfrentamento de problemas é mais comum entre os que a consideram importante e relevante em suas vidas.

As pessoas buscam alternativas complementares e suplementares para o enfrentamento dos problemas de saúde por diversas razões, como experiências negativas com profissionais de saúde, falta de recursos financeiros ou até mesmo por pressão social de outros membros de grupos religiosos ${ }^{61}$. As pessoas idosas, além dessas razões, buscam a religião e a espiritualidade atrás de significado da própria vida, conforto, sentido na velhice, na doença e na morte ${ }^{8}$.

É importante ressaltar que a atenção às dimensões biofisiológicas, psicológicas, sociológicas e culturais devem considerar a satisfação das necessidades espirituais. Como, muitas vezes, o envelhecimento pode estar acompanhado por doenças crônicas e limitações físicas, a realização das atividades religiosas pode estar comprometida. Quando há dificuldade em realizá-las ou em poder agir de acordo com suas crenças e valores, ocorre o sofrimento espiritual, que pode ser manifestado por ansiedade, frustração, isolamento ou, até mesmo, dúvida quanto à própria existência ${ }^{8}$.

Para Potter e Perry ${ }^{7}$, o sofrimento espiritual pode ser causado tanto por perdas, lamentações ou doença, como também por contradições entre a crença pessoal e o tratamento de saúde prescrito ou por incapacidade de 
praticar seus rituais usuais, tais situações levam o indivíduo ao isolamento e à solidão, acompanhado de questionamentos sobre o propósito de vida e o significado da existência.

Conhecer o perfil e o comportamento das pessoas idosas quanto à religiosidade e compreender o impacto dessa sobre as condições de vida e saúde desse grupo são de vital importância para a adequação de um planejamento assistencial humanizado e de qualidade, sendo essas as principais motivações do desenvolvimento desse estudo. 
Objetivos 


\section{OBJETIVOS}

\subsection{OBJETIVO GERAL}

Conhecer o perfil religioso e a importância dada à religião pelos idosos residentes no município de São Paulo e sua associação com condições de saúde.

\subsection{OBJETIVOS ESPECÍFICOS}

- Traçar o perfil religioso dos idosos residentes no município de São Paulo;

- Verificar alterações no perfil religioso desse grupo com:

○ o avançar da idade

- com a presença de doenças/incapacidades

- com alterações nas condições de saúde;

- Associar o perfil religioso e sua importância com as condições de vida e saúde das pessoas idosas. 
Casuística e Método 


\section{CASUÍSTICA E METODO}

\subsection{O Estudo SABE}

Este estudo é parte do Estudo SABE - Saúde, Bem-estar e Envelhecimento, estudo multicêntrico, inicialmente coordenado pela Organização Pan-Americana de Saúde (OPAS), foi iniciado em 2000, em sete centros urbanos da América Latina e Caribe: Buenos Aires (Argentina), Bridgetown (Barbados), São Paulo (Brasil), Santigo (Chile), Havana (Cuba), Cidade do México (México) e Montevidéu (Uruguai) com o objetivo de traçar o perfil das condições de vida e saúde dos idosos da região.

No Brasil, a população de estudo foi composta por pessoas, de ambos os sexos, com idade igual e superior a 60 anos idosos residentes, no ano de 2000, na zona urbana do Município de São Paulo. O cálculo da amostra teve por base a contagem populacional de 1996 da Fundação IBGE (Instituto Brasileiro de Geografia e Estatística). Foi utilizado o cadastro permanente de 72 setores censitários existentes na Faculdade de Saúde Pública da Universidade de São Paulo, coordenadora do estudo em nosso país, selecionados sob o critério de probabilidade proporcional ao número de domicílios do cadastro da Pesquisa Nacional por Amostras de Domicílios (PNAD), de 1995. Posteriormente, foram sorteados sistematicamente os domicílios a serem visitados. A complementação da amostra de pessoas de 75 anos e mais foi realizada pela localização de moradias próximas aos setores selecionados ou, no máximo, dentro dos limites dos distritos aos 
quais pertenciam os setores sorteados. Para a análise dos resultados, foi atribuído a cada questionário um peso relativo à sua representatividade na população.

Após a seleção da amostra, os idosos foram entrevistados em seus domicílios, sendo a maior parte das entrevistas feita de forma direta (88\%) e, quando isso não era possível por impossibilidade física ou cognitiva do idoso, utilizou-se um informante auxiliar (complementar ao idoso) ou substituto (proxi-respondente). A taxa de respostas foi de $84,6 \%$ representando 2.143 idosos (Coorte $A_{00}$ ). Este total correspondeu a $92 \%$ da meta originalmente prevista, que é considerada satisfatória para este tipo de estudo.

Os idosos foram entrevistados em domicílio por meio de instrumento padronizado composto por onze seções (Anexo 1 em CD) ${ }^{3,64:}$

- Seção A. Dados Pessoais

Ano e país de nascimento; local de residência durante os primeiros 15 anos de vida; local de residência durante os últimos 5 anos de vida e, onde fosse aplicável, razões para a mudança de residência; história e estado marital; número de filhos; sobrevivência dos pais, e, se não, a idade em que faleceram; escolaridade.

- Seção B. Avaliação Cognitiva 
Autoavaliação da memória; avaliação da demora pelo teste minimental modificado e validado no Chile para realização do estudo. Para os que obtivessem escore igual ou inferior a 12 pontos, uma escala de desempenho funcional era administrada a um proxi-respondente (informante substituto) com base na questão "é capaz de...".

○ Seção C. Estado de Saúde

Autoavaliação de saúde atual e comparativa ao ano anterior, bem como da saúde na infância; doenças referidas, considerando nove das condições crônicas mais prevalentes na população idosa e incluindo seu tratamento; hábitos, condições sensoriais; saúde reprodutiva; saúde bucal; ocorrência de quedas; escala de avaliação de depressão geriátrica e mini screening nutricional.

○ Seção D. Estado Funcional

Avaliação do desempenho funcional e da ajuda recebida, quando necessária, nas atividades básicas e instrumentais da vida diária e identificação e caracterização do(s) cuidador(es) principal(ais).

- Seção E. Medicamentos

Terapêutica medicamentosa utilizada, incluindo identificação, tempo de uso, forma de utilização, obtenção e pagamento; gastos mensais com 
medicamentos e motivos referidos para não utilização dos medicamentos prescritos.

- Seção F. Uso e acesso a serviços

Serviços de saúde utilizados, públicos ou privados, nos últimos 12 meses e ocorrência de hospitalização, atendimento ambulatórias, exames nos últimos 4 meses, bem como tempo de espera para atendimento, terapêutica prescrita e gastos relacionados.

- Seção G. Rede de apoio familiar e social

Número e características de pessoas que vivem com o idoso no mesmo domicílio (sexo, parentesco, estado marital, idade, escolaridade e condição de trabalho), assistência prestada ao idoso e fornecida por ele referente a cada membro citado; tempo gasto na ajuda ao idoso. As mesmas perguntas foram feitas em relação aos irmãos e filhos que não vivem no mesmo domicílio, bem como a outros familiares e que, de alguma forma, fornecem ou recebem ajuda do/ao idoso; assistência fornecida ou recebida nos últimos 12 meses de alguma instituição ou organização; participação do idoso em algum serviço voluntário ou organização comunitária.

- Seção H. História laboral e fonte de renda

Trabalho atual (tipo, renda, razões para continuar trabalhando); caso não trabalhasse mais, por que não o fazia, ocupação que teve durante o 
maior período da sua vida, horas trabalhadas, razões para mudar de atividade, pensões, aposentarias, benefícios, outras fontes de renda, renda total pessoal e número de dependentes dessa renda; gastos pessoais (moradia, transporte, alimentação, vestimenta, saúde) e autoavaliação de bem-estar econômico.

○ Seção J. Característica de moradia

Tipo e propriedade da moradia, condições de habitação (saneamento básico, luz, número de cômodos, bens presentes).

- Seção K. Dados Antropométricos

Altura do joelho, circunferência do braço, cintura, quadril, prega triciptal, peso, circunferência de panturrilha, largura do punho e força da mão.

○ Seção L. Testes de equilíbrio, flexibilidade e mobilidade.

Provas de equilíbrio, mobilidade e flexibilidade.

Em 2006, com o intuito de estudar o impacto do tempo nas condições de vida e saúde dos idosos e os determinantes e fatores de risco associados às alterações encontradas, o Estudo SABE transformou-se em um estudo longitudinal. Para tanto, os idosos da coorte $A_{00}$ foram localizados $e$ reentrevistados. O instrumento utilizado manteve seu eixo original, sendo 
incluídas ou alteradas questões cujas respostas não foram satisfatórias em 2000 (Anexo 2 em CD).

$\mathrm{Na}$ segunda coleta de dados foram reentrevistadas 1.115 pessoas, nesse momento com idade igual e superior a 65 anos (coorte $A_{06}$ ) sendo a diferença composta por óbitos, institucionalizações, mudanças para outros municípios, não localizações e recusas.

Tabela 1 - Evolução da amostra de idosos do Estudo SABE no período de 2000 a 2006. São Paulo, 2000-2006.

\begin{tabular}{lrr}
\hline \multicolumn{1}{c}{ SITUAÇÃo FINAL } & $\begin{array}{c}\text { Número de } \\
\text { idosos }\end{array}$ & $\%$ \\
\hline Amostra em 2000 $\left(\mathrm{A}_{00}\right)$ & 2.143 & 100,0 \\
Óbitos & 649 & 30,3 \\
Mudanças & 191 & 8,9 \\
$\quad$ outros municípios & 52 & 2,4 \\
$\quad$ não localizados & 139 & 6,5 \\
Idosos institucionalizados & 11 & 0,5 \\
Recusas & 177 & 8,3 \\
Entrevistas realizadas em 2006 $\left(\mathrm{A}_{06}\right)$ & 1.115 & 52,0 \\
\hline
\end{tabular}

Fonte: Estudo SABE 2000-2006

\subsection{Análise dos dados do Estudo SABE}

Para esse estudo foram utilizados os dados relacionados à população idosa do Estudo SABE 2000 (coorte $A_{00}$ ) e 2006 (coorte $A_{06}$ ). Para as análises, foi utilizado o Qui-quadrado de Pearson, ajustado pelo Rao Scott e o nível de confiança estabelecido foi de $95 \%{ }^{65}$.

As variáveis selecionadas deste estudo apresentaram nível crítico $p<20$ e o nível de confiança adotado foi e $55 \%(p<0,05)$.

Para analise dos dados utilizou-se o programa Stata 0 (Stata Corp. College Station, Estado Unidos), versão 11. 
As questões sobre religião encontram-se na Seção A - Informações Pessoais. Em 2000 havia apenas duas questões específicas e, em 2006, foram incluídas questões adicionais como mostra o quadro 1:

Quadro 1 - Questões do Estudo SABE relacionadas à religião nos anos 2000 e 2006.São Paulo, 2000 e 2006.

\begin{tabular}{|l|c|c|}
\hline QUESTÕES & 2000 & 2006 \\
\hline Qual é sua religião? & A.11a & A.11a \\
\hline Qual a importância da religião em sua vida? & A.11b & A.11b \\
\hline Com que freqüência o(a) Sr.(a) vai a igreja ou ao serviço religioso? & - & A.11c \\
\hline Quanto sua religião Ihe dá forças para enfrentar dificuldades? & - & A.11d \\
\hline Quanto sua religião o(a) ajuda a entender as dificuldades da vida? & - & A.11e \\
\hline Sua religião dá sentido a sua vida? & - & A.11f \\
\hline $\begin{array}{l}\text { Utilizando sua própria definição de pessoa religiosa, o quanto o(a) } \\
\text { Sr.(a) se considera religioso(a)? }\end{array}$ & - & A.11g \\
\hline $\begin{array}{l}\text { Com que freqüência o(a) Sr.(a) reza (ora) ou realiza suas práticas } \\
\text { religiosas? }\end{array}$ & - & A.11h \\
\hline Fonte: Estudo SABE, 2000/2006. & \\
\hline
\end{tabular}

Fonte: Estudo SABE, 2000/2006.

Fizeram parte desse estudo os idosos que responderam as questões A.11a e A.11b em 2000 e de A.11a a A.11h em 2006. O perfil religioso foi traçado nos dois momentos e as mudanças no período foram obtidas por meio da comparação das respostas das duas coortes. O impacto nas condições de vida e saúde foi analisado a partir da importância referida à religião em 2000 e de sua comparação com as condições de vida e saúde em 2006.

As variáveis dependentes foram: 


\begin{tabular}{|l|c|}
\hline \multicolumn{1}{|c|}{ Variável } & Questão \\
\hline Qual é sua religião? & A.11a \\
\hline Qual a importância da religião em sua vida? & A.11b \\
\hline
\end{tabular}

O quadro 2 apresenta as variáveis independentes e utilizadas na construção do estudo:

Quadro 2 - Variáveis independentes, tipo, categoria e referência no questionário. Estudo SABE. São Paulo, 2000-2006.

\begin{tabular}{|c|c|c|c|}
\hline $\begin{array}{c}\text { Variáveis } \\
\text { Independentes } \\
\end{array}$ & & & \\
\hline Variável & $\begin{array}{l}\text { Tipo de } \\
\text { variável }\end{array}$ & Categorias & Questão \\
\hline Idade & $\begin{array}{l}\text { Quantitativa } \\
\text { Ordinal }\end{array}$ & Anos completos & A. $1 b$ \\
\hline Sexo & $\begin{array}{l}\text { Qualitativa } \\
\text { Nominal }\end{array}$ & Homem, Mulher & C. 18 \\
\hline $\begin{array}{c}\text { Escolaridade } \\
\text { (em anos de estudo) }\end{array}$ & $\begin{array}{l}\text { Qualitativa } \\
\text { Ordinal }\end{array}$ & $\begin{array}{c}\text { Analfabeto, } 1-3,4-7,8 \\
\text { e mais }\end{array}$ & A.06 \\
\hline Estado Marital & $\begin{array}{l}\text { Qualitativa } \\
\text { Nominal }\end{array}$ & $\begin{array}{l}\text { Com vida conjugal, } \\
\text { divorciado, viúvo }\end{array}$ & A.06 \\
\hline $\begin{array}{c}\text { Renda (salários } \\
\text { mínimos) }\end{array}$ & $\begin{array}{l}\text { Quantitativa } \\
\text { Ordinal }\end{array}$ & $0, \leq 1,1-3,3-5,>5$ & H.3, H.27a \\
\hline Arranjo Unipessoal & $\begin{array}{l}\text { Qualitativa } \\
\text { Nominal }\end{array}$ & Sim, Não & A. 07 \\
\hline $\begin{array}{l}\text { Mudança no número de } \\
\text { doenças referidas }\end{array}$ & $\begin{array}{c}\text { Quantitativa } \\
\text { discreta }\end{array}$ & Nenhuma, 1,2 e mais & $\begin{array}{l}\text { C4, C5, C6, } \\
\text { C7, C8, C9, } \\
\text { C10 }\end{array}$ \\
\hline $\begin{array}{l}\text { Autopercepção de } \\
\text { saúde }\end{array}$ & $\begin{array}{l}\text { Qualitativa } \\
\text { Nominal }\end{array}$ & $\begin{array}{l}\text { Excelente/muito } \\
\text { boa/boa, regular, } \\
\text { ruim/muito ruim }\end{array}$ & C1, C2,C3 \\
\hline Sintomas depressivos & $\begin{array}{l}\text { Qualitativa } \\
\text { Nominal }\end{array}$ & Sim, Não & C20b2,C20c \\
\hline $\begin{array}{l}\text { Dificuldade referida no } \\
\text { desempenho das } \\
\text { atividades básicas da } \\
\text { vida diária (ABVDs) }\end{array}$ & $\begin{array}{l}\text { Quantitativa } \\
\text { Discreta }\end{array}$ & Nenhuma, 1 ou mais & $\begin{array}{l}\text { D11, D13a, } \\
\text { D14a, D15a, } \\
\text { D16a, D17a }\end{array}$ \\
\hline $\begin{array}{c}\text { Dificuldade referida no } \\
\text { desempenho das } \\
\text { atividades } \\
\text { instrumentais da vida } \\
\text { diária (AIVDs) }\end{array}$ & $\begin{array}{l}\text { Quantitativa } \\
\text { Discreta }\end{array}$ & Nenhuma, 1 ou mais & $\begin{array}{l}\text { D18, D19a, } \\
\text { D20a, D21a, } \\
\text { D22a, D23a, } \\
\text { D24a, D25a }\end{array}$ \\
\hline $\begin{array}{c}\text { Presença de declínio } \\
\text { cognitivo }\end{array}$ & $\begin{array}{l}\text { Qualitativa } \\
\text { Nominal }\end{array}$ & Sim, Não & $\mathrm{B} 1, \mathrm{~B} 2$ a B18 \\
\hline
\end{tabular}

Fonte: Estudo SABE 2000/2006. 
A apresentação dos resultados foi feita por meio de freqüência descritiva em tabelas.

\subsection{Aspectos Éticos}

O Estudo SABE foi submetido e aprovado pelo comitê de Ética e Pesquisa da Faculdade de Saúde Pública da Universidade de São Paulo e pelo CONEP, Conselho Nacional de Ética em Pesquisa, sob o parecer número 315/99 para o ano 2000 (Anexo 3) e Protocolo número 1345 de 14/03/2006 para o ano de 2006 (Anexo 4).

Os sujeitos que participaram da pesquisa assinaram o termo de consentimento livre e esclarecido (Anexo 5) e tiveram assegurados o sigilo das informações, anonimato e o direito da desistência da participação do estudo a qualquer momento, conforme postulado pela Resolução 196/96.

Nas duas fases, o Estudo SABE contou com financiamento da Fundação de Amparo à Pesquisa do estado de São Paulo - FAPESP e com auxílio do Ministério da Saúde. 
Resultados 


\section{RESULTADOS}

Os resultados desse estudo serão apresentados em quatro partes:

a) Caracterização da amostra segundo religião referida, sexo e faixa etária;

b) Importância dada à religião, segundo o perfil sócio-demográfico e condições de saúde;

c) Freqüência de participação nos cultos religiosos e significado pessoal atribuído à religião (força para o enfrentamento e a compreensão das dificuldades da vida, sentido à vida);

d) Modificação da religião referida entre 2000 e 2006.

\subsection{Perfil religioso}

Em 2000, 97,6\% dos idosos referiram pertencer a alguma religião. Em 2006, essa proporção foi de $98 \%$, muito similar ao anteriormente encontrado.

As principais religiões referidas em 2000 foram: católica $(71,0 \%)$, evangélica $(19,6 \%)$ e espírita $(3,8 \%)$, judaica $(0,1 \%)$, oriental $(2,7 \%)$ e outras (0,6\%). Em 2006, mantém-se a mesma sequencia embora com proporções diferentes: católicos (69,3\%), evangélicos (19,6\%), espíritas (3,6\%), protestantes $(0,7 \%)$, budistas $(1,7 \%)$ e "outras" $(3,1 \%)$. Apenas $2,4 \%$ dos idosos em 2000 referiram não pertencer a "nenhuma religião" e essa proporção diminuiu para 1,9\% em 2006. 
Para as análises posteriores, os protestantes foram unidos aos evangélicos e os orientais aos budistas. As respostas "não sabe" ou não responde" foram desconsideradas (missing).

A Tabela 2 apresenta a distribuição do perfil dos idosos segundo religião referida, sexo e faixa etária:

Tabela 2 - Distribuição (\%) dos idosos segundo religião referida, sexo e idade. São Paulo, 2000 e 2006.

\begin{tabular}{|c|c|c|c|c|c|c|c|c|}
\hline \multirow{4}{*}{ Religião } & \multicolumn{8}{|c|}{$\%$} \\
\hline & \multicolumn{4}{|c|}{2000} & \multicolumn{4}{|c|}{2006} \\
\hline & \multicolumn{2}{|c|}{ Sexo } & \multicolumn{2}{|c|}{ Faixa Etária } & \multicolumn{2}{|c|}{ Sexo } & \multicolumn{2}{|c|}{ Faixa Etária } \\
\hline & $\begin{array}{l}\text { Homem } \\
(n=881)\end{array}$ & $\begin{array}{c}\text { Mulher } \\
(n=1262)\end{array}$ & $\begin{array}{c}60 \text { a } 74 \\
(n=1141)\end{array}$ & $\begin{array}{c}75 e+ \\
(n=1002)\end{array}$ & $\begin{array}{c}\text { Homem } \\
(n=412)\end{array}$ & $\begin{array}{l}\text { Mulher } \\
(\mathrm{n}=700)\end{array}$ & $\begin{array}{r}60 \text { a } 74 \\
(n=427)\end{array}$ & $\begin{array}{c}75 \mathrm{e}+ \\
(\mathrm{n}=685)\end{array}$ \\
\hline Católica & 73,3 & 69,3 & 69,7 & 75,5 & 71,0 & 68,5 & 68,1 & 76,9 \\
\hline Evangélica & 16,3 & 21,7 & 20,6 & 15,4 & 17,9 & 21,7 & 21,2 & 15,0 \\
\hline Espírita & 3,1 & 4,2 & 3,8 & 3,5 & 3,3 & 3,8 & 3,7 & 2,9 \\
\hline Judaica & 0,2 & 0,1 & 0,1 & 0,2 & - & - & - & - \\
\hline Oriental & 2,2 & 3,1 & 2,7 & 2,7 & - & - & - & - \\
\hline Budista & - & - & - & - & 1,5 & 1,8 & 1,4 & 3,0 \\
\hline Nenhum & 4,4 & 1,0 & 2,4 & 2,4 & 3,7 & 0,7 & 2,0 & 1,4 \\
\hline Outro & 0,5 & 0,6 & 0,6 & 0,4 & 2,6 & 3,4 & 3,6 & 0,8 \\
\hline \multicolumn{3}{|c|}{$(p=0,001)$} & & & & & \multicolumn{2}{|c|}{$(p=0,0128)$} \\
\hline Total & 100,0 & 100,0 & 100,0 & 100,0 & 100,0 & 100,0 & 100,0 & 100,0 \\
\hline
\end{tabular}

A maior proporção de idosos, nos dois períodos, encontra-se entre os católicos seguidos pelos evangélicos/protestantes. Em relação às diferenças de gênero observa-se que, entre os homens há maior referencia da religião católica e judaica e entre as mulheres, evangélica/protestante, espírita e orientais/budistas. Verifica-se uma maior proporção entre os que referiram "outras religiões" em 2006. Os homens também apresentam maior proporção entre os que não referem nenhuma religião.

Quanto à idade, observa-se uma maior proporção de católicos entre os mais longevos e uma diminuição dessa proporção entre os que não 
referem nenhuma religião com o transcorrer do tempo $(2,4 \%$ em 2000 para 1,7\% em 2006).

5.2 Religião referida e perfil sociodemográfico

A tabela 3 mostra o perfil sociodemográfico dos idosos que responderam ter ou não religião.

Tabela 3 - Distribuição (\%) dos idosos segundo referência de crença religiosa e características sócio-demográficas. São Paulo, 2000 e 2006.

\begin{tabular}{|c|c|c|c|c|}
\hline & \multicolumn{4}{|c|}{ Religiao referida (\%) } \\
\hline & \multicolumn{2}{|c|}{2000} & \multicolumn{2}{|c|}{2006} \\
\hline & $\operatorname{Sim}(n=2095)$ & Não (n=48) & $\operatorname{Sim}(n=1094)$ & Não (n=18) \\
\hline \multicolumn{5}{|l|}{ Sexo } \\
\hline Homem & 95,6 & 4,4 & 96,3 & 3,7 \\
\hline \multirow[t]{2}{*}{ Mulher } & 99,0 & 1,0 & 99,3 & 0,7 \\
\hline & \multicolumn{2}{|c|}{$(p=0,0000)$} & \multicolumn{2}{|c|}{$\quad(p=0,0155)$} \\
\hline \multicolumn{5}{|l|}{ Faixa Etária } \\
\hline 60 a 74 & 97,6 & 2,4 & 98,0 & 2,0 \\
\hline \multirow[t]{2}{*}{$75 e+$} & 97,6 & 2,4 & 98,6 & 1,4 \\
\hline & \multicolumn{2}{|c|}{$(p=0,9708)$} & \multicolumn{2}{|c|}{$(p=0,4968)$} \\
\hline \multicolumn{5}{|l|}{ Estado Marital } \\
\hline Com vida Conjugal & 97,5 & 2,5 & 97,9 & 2,1 \\
\hline Divorciado & 95,5 & 4,5 & 97,0 & 3,0 \\
\hline \multirow[t]{2}{*}{ Viúvo } & 98,8 & 1,2 & 98,7 & 1,3 \\
\hline & \multicolumn{2}{|c|}{$(p=0,0426)$} & \multicolumn{2}{|c|}{$(p=0,5818)$} \\
\hline \multicolumn{5}{|l|}{ Arranjo Unipessoal } \\
\hline Sim & 97,7 & 2,3 & 98,1 & 1,9 \\
\hline \multirow[t]{2}{*}{ Não } & 97,6 & 2,4 & 98,3 & 1,7 \\
\hline & \multicolumn{2}{|c|}{$(p=0,9639)$} & \multicolumn{2}{|c|}{$(p=0,9167)$} \\
\hline \multicolumn{5}{|l|}{ Escolaridade } \\
\hline 8 anos $e+$ & 96,1 & 3,9 & 95,7 & 4,3 \\
\hline 4 a 7 anos & 98,4 & 1,6 & 98,8 & 1,2 \\
\hline 1 a 3 anos & 97,5 & 2,5 & 98,4 & 1,6 \\
\hline analfabeto & 97,6 & 2,4 & 98,5 & 1,5 \\
\hline & \multicolumn{2}{|c|}{$(p=0,1615)$} & \multicolumn{2}{|c|}{$(p=0,1706)$} \\
\hline \multicolumn{5}{|l|}{ Renda (SI Mínimo) } \\
\hline Sem renda & 99,6 & 0,4 & 99,4 & 0,6 \\
\hline$<1$ & 97,8 & 2,2 & 98,3 & 1,7 \\
\hline 1 a 2,99 & 97,4 & 2,6 & 98,6 & 1,4 \\
\hline 3 a 4,99 & 98,4 & 1,6 & 95,3 & 4,7 \\
\hline$>5$ & 96,7 & 3,3 & 99,4 & 0,6 \\
\hline & \multicolumn{2}{|c|}{$(p=0,1994)^{3,3}$} & \multicolumn{2}{|c|}{$(p=0,2471)$} \\
\hline
\end{tabular}

Fonte: Estudo SABE, 2000 e 2006.

Verifica-se que a maioria dos idosos refere um credo religioso sendo mais predominante entre as mulheres $(p=0,0000$ em 2000 e $p=0,0155$ em 2006) e entre os viúvos ( $p=0,0426)$. Não foram observadas diferenças estatisticamente significativas entre a idade e a condição de moradia. 
Embora renda e escolaridade também não tenham apresentado diferença estatisticamente significativa entre ter ou não uma crença religiosa, observase que, entre os idosos que não referem nenhuma crença, a maior concentração situa-se entre os de maior renda e maior escolaridade.

$\mathrm{Na}$ tabela 4 podem ser observados os resultados relacionados a ter ou não uma crença religiosa e condições de saúde/doença.

Tabela 4 - Distribuição (\%) dos idosos segundo referência de crença religiosa e condições de saúde/doença. São Paulo, 2000 e 2006.

\begin{tabular}{|c|c|c|c|c|}
\hline \multicolumn{5}{|c|}{ Religião referida (\%) } \\
\hline \multirow{2}{*}{$\begin{array}{l}\text { Condições de } \\
\text { Saúde/Doença }\end{array}$} & \multicolumn{2}{|c|}{2000} & \multicolumn{2}{|c|}{2006} \\
\hline & $\operatorname{Sim}(n=2095)$ & Não $(n=48)$ & $\operatorname{Sim}(n=1094)$ & Não $(n=18)$ \\
\hline \multicolumn{5}{|c|}{ Número de doenças referidas } \\
\hline Nenhuma & 95,8 & 4,2 & 95,5 & 4,5 \\
\hline Uma & 97,7 & 2,3 & 99,0 & 1,0 \\
\hline \multirow[t]{2}{*}{$2 o u+$} & 98,5 & 1,5 & 98,3 & 1,7 \\
\hline & \multicolumn{2}{|c|}{$(p=0,0260)$} & \multicolumn{2}{|c|}{$(p=0,1946)$} \\
\hline \multicolumn{5}{|c|}{ Autopercepção de Saúde referida } \\
\hline Excelente/Muito boa/Boa & 97,9 & 2,1 & 97,5 & 2,5 \\
\hline Regular & 97,4 & 2,6 & 99,4 & 0,6 \\
\hline Ruim/Muito Ruim & 97,0 & 3,0 & 94,4 & 5,6 \\
\hline & \multicolumn{2}{|c|}{$(p=0,6415)$} & \multicolumn{2}{|c|}{$(p=0,0224)$} \\
\hline \multicolumn{5}{|l|}{ Sintomas depressivos } \\
\hline Sim & 98,0 & 2,0 & 99,7 & 0,3 \\
\hline \multirow[t]{2}{*}{ Não } & 97,9 & 2,1 & 97,9 & 2,1 \\
\hline & \multicolumn{2}{|c|}{$(p=0,9236)$} & \multicolumn{2}{|c|}{$(p=0,0318)$} \\
\hline \multicolumn{5}{|c|}{ Dificuldade no desempenho de ABVDs $(\geq 1)$} \\
\hline Sim & 98,2 & 1,8 & 98,4 & 1,6 \\
\hline \multirow[t]{2}{*}{ Não } & 97,5 & 2,5 & 98,0 & 2,0 \\
\hline & \multicolumn{2}{|c|}{$(p=0,9252)$} & \multicolumn{2}{|c|}{$(p=0,7590)$} \\
\hline \multicolumn{5}{|c|}{ Dificuldade no desempenho de AIVDs $(\geq 1)$} \\
\hline Sim & 97,6 & 2,4 & 98,7 & 1,3 \\
\hline \multirow[t]{2}{*}{ Não } & 97,6 & 2,4 & 97,7 & 2,3 \\
\hline & \multicolumn{2}{|c|}{$(p=0,9252)$} & \multicolumn{2}{|c|}{$(p=0,2761)$} \\
\hline \multicolumn{3}{|c|}{ Presença de declínio cognitivo } & & \\
\hline Sim & 95,5 & 4,5 & 98,8 & 1,2 \\
\hline Não & 97,9 & 2,1 & 98,0 & 2,0 \\
\hline & $(p=0$ & 47) & \multicolumn{2}{|c|}{$(p=0,5633)$} \\
\hline
\end{tabular}

Fonte: Estudo SABE, 2000 e 2006.

Referir um maior número de doenças e uma saúde em piores condições mostrou-se estatisticamente significativo entre os idosos que referem ou não um credo religioso sendo que a proporção dessas variáveis entre os que referem não ter um credo é maior. Quanto aos sintomas depressivos, houve associação estatisticamente significativa apenas em 
$2006(p=0,0318)$. Com relação à presença de incapacidades, as proporções foram muito semelhantes nos dois períodos analisados e não mostraram diferença estatística. Em 2000, verifica-se diferença entre os idosos com e sem declínio cognitivo ( $p=0,0347)$, com maior proporção entre os sem declínio.

A análise da importância atribuída pelos idosos à religião (entre os que referiram alguma crença) observa-se que, apesar de sua relevância em 2000 (88,8\%), ela passa a ser ainda mais expressiva em $2006(92,7 \%)$. Na tabela 5 essa análise está estratificada segundo características sociodemográficas.

A importância atribuída à religião é maior entre as mulheres e essa proporção aumenta com o passar do tempo $(p=0,0000$ e $p=0,0013$, respectivamente). Isso também ocorre entre os mais longevos e os menos escolarizados. Observa-se que tanto com relação à escolaridade quanto à renda, há uma distribuição inversamente proporcional com relação à importância atribuída à religião. Não foi observada associação com relação à condição de moradia, mas o foi em relação ao estado marital. Nesse observa-se maior importância atribuída à religião entre os que não possuem companheiro. Observa-se certa influencia da passagem do tempo na importância atribuída à religião pois, em 2006, a proporção dos que a consideravam "nada importante" diminuiu (tabela 5). 
Tabela 5 - Distribuição (\%) dos idosos segundo importância atribuída à religião em sua vida e características sociodemográficas. São Paulo, 2000 e 2006.

\begin{tabular}{|c|c|c|c|c|c|c|}
\hline \multirow{3}{*}{$\begin{array}{l}\text { Características } \\
\text { sócio- } \\
\text { demográficas }\end{array}$} & \multicolumn{6}{|c|}{$\begin{array}{c}\text { Importância da Religião } \\
\%\end{array}$} \\
\hline & \multicolumn{3}{|c|}{2000} & \multicolumn{3}{|c|}{2006} \\
\hline & $\begin{array}{c}\text { Importante } \\
(\mathrm{n}=1646)\end{array}$ & $\begin{array}{c}\text { Regular } \\
(n=153)\end{array}$ & $\begin{array}{c}\text { Nada } \\
\text { Importante } \\
(n=34)\end{array}$ & $\begin{array}{l}\text { Importante } \\
(\mathrm{n}=967)\end{array}$ & $\begin{array}{c}\text { Regular } \\
(n=58)\end{array}$ & $\begin{array}{c}\text { Nada } \\
\text { Importante } \\
(n=15)\end{array}$ \\
\hline \multicolumn{7}{|l|}{ Sexo } \\
\hline Homem & 82,4 & 14,7 & 2,8 & 88,3 & 9,3 & 2,4 \\
\hline Mulher & 93,1 & $\begin{array}{c}5,6 \\
(p=0,0000)\end{array}$ & 1,2 & 95,4 & $\begin{array}{c}4,1 \\
(p=0,0013)\end{array}$ & 0,5 \\
\hline \multicolumn{7}{|l|}{ Faixa Etária } \\
\hline 60 a 74 & 88,2 & 9,8 & 1,9 & 92,3 & 6,5 & 1,2 \\
\hline 75 e mais & 91,2 & $\begin{array}{c}7,2 \\
(p=0,2124)\end{array}$ & 1,6 & 95,2 & $\begin{array}{c}3,6 \\
(p=0,5634)\end{array}$ & 1,3 \\
\hline \multicolumn{7}{|l|}{ Estado Marital } \\
\hline $\begin{array}{l}\text { Com vida } \\
\text { conjugal }\end{array}$ & 86,4 & 11,5 & 2,1 & 90,9 & 7,2 & 1,9 \\
\hline Viúvo & 92,1 & 6,5 & 1,4 & 93,9 & 5,5 & 0,6 \\
\hline Divorciado & 91,9 & $\begin{array}{c}6,6 \\
(p=0,0426)\end{array}$ & 1,5 & 95,4 & $\begin{array}{c}4,6 \\
(p=0,2806)\end{array}$ & 0,0 \\
\hline \multicolumn{7}{|c|}{ Arranjo Unipessoal } \\
\hline Sim & 91,2 & 6,2 & 2,5 & 94,4 & 5,0 & 0,6 \\
\hline Não & 88,4 & $\begin{array}{c}9,8 \\
(p=0,3533)\end{array}$ & 1,8 & 92,4 & $\begin{array}{c}6,3 \\
(p=0,4935)\end{array}$ & 1,3 \\
\hline \multicolumn{7}{|l|}{ Escolaridade } \\
\hline 8 anos $e+$ & 84,6 & 10,5 & 4,9 & 89,0 & 8,0 & 3,0 \\
\hline 4 a 7 anos & 87,1 & 11,6 & 1,3 & 92,0 & 6,4 & 1,7 \\
\hline 1 a 3 anos & 89,1 & 9,1 & 1,8 & 94,7 & 5,0 & 0,3 \\
\hline analfabeto & 95,5 & $\begin{array}{c}4,3 \\
(p=0,0002)\end{array}$ & 0,2 & 94,2 & $\begin{array}{c}5,5 \\
(p=0,1097)\end{array}$ & 0,3 \\
\hline \multicolumn{7}{|c|}{ Renda (SI Mínimo) } \\
\hline Sem renda & 92,2 & 6,7 & 1,1 & 97,4 & 2,6 & 0,0 \\
\hline$<1$ & 88,6 & 9,4 & 2,0 & 96,4 & 3,6 & 0,0 \\
\hline 1 a 2,99 & 90,9 & 7,5 & 1,6 & 92,4 & 6,3 & 1,3 \\
\hline 3 a 4,99 & 88,9 & 8,6 & 2.5 & 89,6 & 9,3 & 1,1 \\
\hline$>5$ & 85,9 & $\begin{array}{c}12,4 \\
(p=0,3606)\end{array}$ & 1,7 & 88,7 & $\begin{array}{c}8,1 \\
(p=0,0907)\end{array}$ & 3.3 \\
\hline
\end{tabular}

Fonte: Estudo SABE, 2000 e 2006.

$\mathrm{Na}$ tabela 6 podem ser observados os resultados relacionados à importância atribuída à religião e as condições de saúde/doença. 
Tabela 6 - Distribuição (\%) dos idosos segundo importância atribuída à religião em sua vida e condições de saúde/doença. São Paulo, 2000 e 2006.

\begin{tabular}{|c|c|c|c|c|c|c|}
\hline \multirow{3}{*}{$\begin{array}{l}\text { Condições de } \\
\text { Saúde/ Doença }\end{array}$} & \multicolumn{6}{|c|}{ Importância da Religião (\%) } \\
\hline & \multicolumn{3}{|c|}{2000} & \multicolumn{3}{|c|}{2006} \\
\hline & $\begin{array}{c}\text { Importante } \\
(n=1646)\end{array}$ & $\begin{array}{l}\text { Regular } \\
(n=153)\end{array}$ & $\begin{array}{c}\text { Nada } \\
\text { Importante } \\
(n=34)\end{array}$ & $\begin{array}{c}\text { Importante } \\
(n=967)\end{array}$ & $\begin{array}{c}\text { Regular } \\
(n=58)\end{array}$ & $\begin{array}{c}\text { Nada } \\
\text { Importante } \\
(n=15)\end{array}$ \\
\hline \multicolumn{7}{|c|}{ Número de Doenças referidas } \\
\hline Nenhuma & 88,1 & 9,7 & 2,2 & 92,6 & 5,2 & 2,2 \\
\hline Uma & 89,0 & 8,8 & 2,2 & 92,1 & 5,2 & 2,7 \\
\hline $2 o u+$ & 88,9 & $\begin{array}{c}9,5 \\
(\mathrm{p}=0,9522)\end{array}$ & 1,6 & 93,0 & $\begin{array}{c}6,7 \\
(p=0,0875)\end{array}$ & 0,3 \\
\hline \multicolumn{7}{|c|}{ Autopercepção de Saúde referida } \\
\hline $\begin{array}{c}\text { Excelente/Muito } \\
\text { boa/Boa }\end{array}$ & 90,7 & 7,4 & 1,9 & 92,6 & 6,2 & 1,2 \\
\hline Regular & 87,4 & 11,2 & 1,4 & 93,5 & 6,0 & 0,5 \\
\hline Ruim/Muito Ruim & 84,2 & $\begin{array}{c}10,5 \\
(p=0,0184)\end{array}$ & 5,3 & 89,3 & $\begin{array}{c}5,7 \\
(p=0,0348)\end{array}$ & 4,9 \\
\hline \multicolumn{7}{|c|}{ Sintomas depressivos } \\
\hline $\operatorname{sim}$ & 86,8 & 9,3 & 3,8 & 95,6 & 3,6 & 0,8 \\
\hline Não & 89,2 & 9,4 & 1,4 & 92,4 & 6,3 & 1,3 \\
\hline & & $(p=0,0712)$ & & & $(p=0,3734)$ & \\
\hline \multicolumn{7}{|c|}{ Dificuldade no desempenho de ABVDs $(\geq 1)$} \\
\hline Sim & 90,2 & 8,4 & 1,4 & 90,9 & 7,8 & 1,3 \\
\hline Não & 88,5 & $\begin{array}{c}9,5 \\
(p=0,7020)\end{array}$ & 2,0 & 93,3 & $\begin{array}{c}5,5 \\
(p=0,4808)\end{array}$ & 1,9 \\
\hline \multicolumn{7}{|c|}{ Dificuldade no desempenho de AIVDs ( $\geq 1)$} \\
\hline $\operatorname{sim}$ & 93,0 & 5,9 & 1,1 & 93,0 & 6,1 & 1,0 \\
\hline Não & 87,7 & $\begin{array}{c}10,2 \\
(\mathbf{p}=\mathbf{0}, \mathbf{0 2 0 2})\end{array}$ & 2,1 & 93,0 & $\begin{array}{c}6,1 \\
(p=0,2761)\end{array}$ & 1,4 \\
\hline \multicolumn{7}{|c|}{ Presença de declínio cognitivo } \\
\hline Sim & 89,3 & 7,9 & 2,8 & 90,6 & 7,1 & 2,2 \\
\hline Não & 88,7 & $\begin{array}{c}9,4 \\
(p=0,7880)\end{array}$ & 1,9 & 93,0 & $\begin{array}{c}5,9 \\
(p=0,4749)\end{array}$ & 1,1 \\
\hline
\end{tabular}

Fonte: Estudo SABE, 2000 e 2006.

Com relação à associação entre a importância atribuída ao credo religioso e às condições de saúde/doença, verifica-se que apenas a autopercepção de saúde e a presença de dificuldade na realização das ABVDs em 2000 mostraram diferença estatisticamente significativas, sendo as maiores proporções de importância atribuídas por aqueles que a avaliam como boa e, da mesma forma, as maiores proporções dos que não a consideram importante são maiores entre os que a avaliam como ruim. Embora não tenha apresentado diferença estatísticamente significativa é interessante observar que, entre as pessoas que apresentavam sintomas 
depressivos, houve um aumento na proporção dos que a consideravam importante entre os dois períodos analisados.

As análises a seguir referem-se apenas à coorte $A_{06}$ pois as questões utilizadas só foram introduzidas no questionário nessa coleta de dados.

\subsection{Religião como fonte de força para o enfrentamento e compreensão das dificuldades da vida e como sentido para a vida}

Um primeiro tópico a ser analisado é a freqüência de participação referida pelos idosos nas atividades que envolvem o credo religioso referido. A maioria referiu ir várias vezes $(26,7 \%)$, seguido por aqueles que vão mais de 1 vez na semana (22,8\%), aqueles que vão quase toda semana $(20,7 \%)$, os que vão uma ou duas vezes por mês (15,3\%). Os que referiram nunca ir foram de menos proporção (14,5\%). Essa participação pode ser, também, analisada segundo sexo e faixa etária (tabela 7).

Verifica-se que $37,3 \%$ dos homens e $47,4 \%$ das mulheres referem freqüência semanal e, a maior proporção dos que referem nunca ir é observada entre os homens. Com relação à idade, $49,6 \%$ dos idosos mais jovens referem freqüência semanal e $21,0 \%$ dos mais longevos referem nunca ir (tabela 7). 
Tabela 7 - Distribuição (\%) dos idosos segundo freqüência referida de participação nas atividades formais relacionadas ao credo religioso referido, sexo e idade. São Paulo, 2006.

\begin{tabular}{|c|c|c|c|c|c|}
\hline & \multicolumn{5}{|c|}{ Frequência com que vão à igreja (\%) } \\
\hline & $\begin{array}{l}\text { Nunca } \\
(n=219)\end{array}$ & $\begin{array}{c}\text { Várias Vezes } \\
\quad(n=284)\end{array}$ & $\begin{array}{c}1 \text { ou } 2 \text { vezes ao } \\
\text { mês }(n=153)\end{array}$ & $\begin{array}{c}\text { Quase toda } \\
\text { semana }(n=203)\end{array}$ & $\begin{array}{l}\text { Mais de } 1 \text { vez na } \\
\text { semana }(n=222)\end{array}$ \\
\hline Sexo & & & & & \\
\hline Homem & 15,1 & 35,1 & 12,5 & 18,1 & 19,2 \\
\hline Mulher & 14,1 & 21,5 & $\begin{array}{c}17,0 \\
(p=0,0004)\end{array}$ & 22,3 & 25,1 \\
\hline $\begin{array}{l}\text { Faixa } \\
\text { Etária }\end{array}$ & & & & & \\
\hline 65 a 74 & 9,0 & 26,6 & 14,8 & 22,9 & 26,7 \\
\hline 75 e mais & 21,0 & 26,9 & $\begin{array}{c}15,8 \\
(p=0,0001)\end{array}$ & 18,1 & 18,2 \\
\hline
\end{tabular}

Fonte: Estudo SABE, 2006.

A maioria dos idosos refere fortalecimento (89,3\%) e auxilio $(87,2 \%)$ para enfrentamento de dificuldades, advindos da religião e referem ainda que essa oferece total ou muito sentido à vida dos mesmos $(87,9 \%)$. $\mathrm{A}$ tabela 8 mostra esses resultados estratificados por sexo e idade (tabela 8).

Tabela 8 - Distribuição (\%) dos idosos segundo fortalecimento e auxílio referidos advindos da religião, para o enfrentamento de dificuldades e sentido à vida fornecido pela mesma, sexo e idade. São Paulo, 2006.

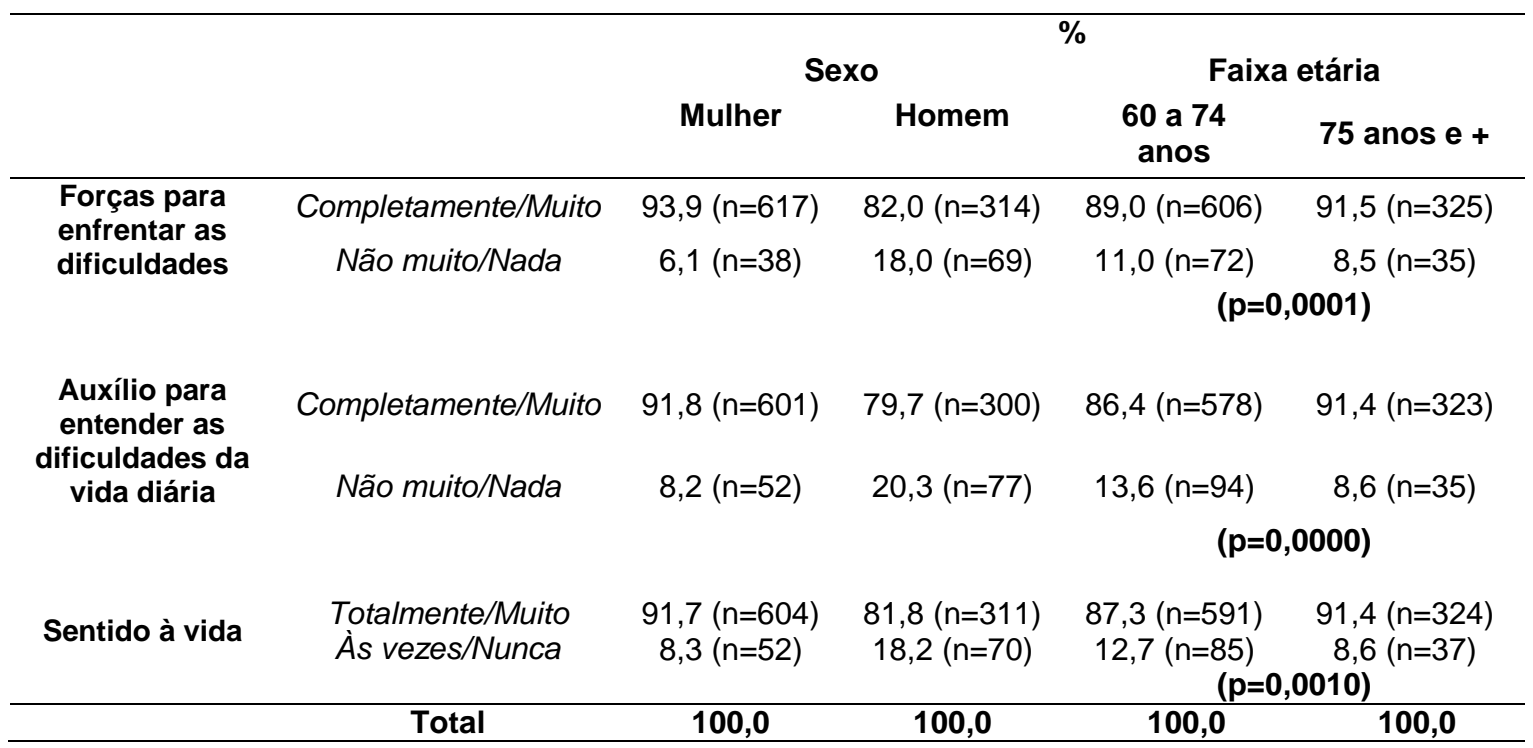

Fonte: Estudo SABE, 2006.

Verifica-se que a religião, para aqueles que a proferem, independente

de qual seja, age como um alicerce na vida das pessoas dando sentido à sua existência, fortalecendo-os e auxiliando-os no enfrentamento das 
dificuldades. Isso é mais expressivo entre as mulheres e entre os idosos mais longevos.

\subsection{Modificação na religião referida}

A opção por um credo religioso está muito relacionada a um conjunto de crenças e valores construído durante a vida. Esses podem ser mais sólidos ou mais superficiais. Em algumas ocasiões, ocorre uma mudança na opção religiosa. Buscou-se verificar se, em um período de seis anos, isso ocorreria com a população idosa do estudo (tabela 9).

Tabela 9 - Distribuição (\%) dos idosos segundo referência de mudança de religião no período de 2000 a 2006. São Paulo, 2000/2006.

\begin{tabular}{|c|c|c|c|c|c|c|c|}
\hline \multirow{2}{*}{$\begin{array}{l}\text { Religião } \\
\text { em } 2000\end{array}$} & \multicolumn{6}{|c|}{$\begin{array}{c}\text { Religião em } 2006 \text { * } \\
(\%)\end{array}$} & \multirow[b]{2}{*}{ Total } \\
\hline & Católico & $\begin{array}{l}\text { Evangélico/ } \\
\text { Protestante }\end{array}$ & Outros & Nenhuma & Espírita & $\begin{array}{l}\text { Oriental/ } \\
\text { Budista }\end{array}$ & \\
\hline Católico & $\begin{array}{c}95,0 \\
(n=753)\end{array}$ & $\begin{array}{c}1,9 \\
(n=13)\end{array}$ & $\begin{array}{c}1,0 \\
(n=6)\end{array}$ & $\begin{array}{c}1,0 \\
(n=5)\end{array}$ & $\begin{array}{c}1,0 \\
(n=8)\end{array}$ & $\begin{array}{c}0,1 \\
(n=1)\end{array}$ & $\begin{array}{c}100,0 \\
(n=786)\end{array}$ \\
\hline $\begin{array}{l}\text { Evangélico/ } \\
\text { Protestante }\end{array}$ & $\begin{array}{c}4,1 \\
(n=10)\end{array}$ & $\begin{array}{c}88,2 \\
(n=201)\end{array}$ & $\begin{array}{c}6,8 \\
(n=15)\end{array}$ & $\begin{array}{c}0,8 \\
(n=2)\end{array}$ & $\begin{array}{c}0,0 \\
(n=0)\end{array}$ & $\begin{array}{c}0,0 \\
(n=0)\end{array}$ & $\begin{array}{c}100,0 \\
(n=228)\end{array}$ \\
\hline Outros & $\begin{array}{l}29,6 \\
(n=1)\end{array}$ & $\begin{array}{c}0,0 \\
(n=0)\end{array}$ & $\begin{array}{l}57,6 \\
(n=2)\end{array}$ & $\begin{array}{c}0,0 \\
(n=0)\end{array}$ & $\begin{array}{c}5,9 \\
(n=1)\end{array}$ & $\begin{array}{c}6,9 \\
(\mathrm{n}=1)\end{array}$ & $\begin{array}{l}100,0 \\
(n=5)\end{array}$ \\
\hline Nenhum & $\begin{array}{l}35,7 \\
(n=9)\end{array}$ & $\begin{array}{l}16,8 \\
(\mathrm{n}=2)\end{array}$ & $\begin{array}{c}0,0 \\
(n=0)\end{array}$ & $\begin{array}{l}47,5 \\
(n=7)\end{array}$ & $\begin{array}{c}0,0 \\
(n=0)\end{array}$ & $\begin{array}{c}0,0 \\
(\mathrm{n}=0)\end{array}$ & $\begin{array}{l}100,0 \\
(n=18)\end{array}$ \\
\hline Espírita & $\begin{array}{c}23,9 \\
(n=12)\end{array}$ & $\begin{array}{c}0,0 \\
(n=0)\end{array}$ & $\begin{array}{c}7,3 \\
(n=3)\end{array}$ & $\begin{array}{c}0,9 \\
(n=2)\end{array}$ & $\begin{array}{c}66,4 \\
(n=29)\end{array}$ & $\begin{array}{c}1,5 \\
(n=1)\end{array}$ & $\begin{array}{l}100,0 \\
(n=47)\end{array}$ \\
\hline $\begin{array}{l}\text { Oriental/ } \\
\text { Budista }\end{array}$ & $\begin{array}{l}10,0 \\
(\mathrm{n}=3)\end{array}$ & $\begin{array}{c}0,0 \\
(n=0)\end{array}$ & $\begin{array}{l}17,5 \\
(n=4)\end{array}$ & $\begin{array}{c}6,3 \\
(n=2)\end{array}$ & $\begin{array}{c}5,8 \\
(n=1)\end{array}$ & $\begin{array}{c}60,4 \\
(n=18)\end{array}$ & $\begin{array}{l}100,0 \\
(n=28)\end{array}$ \\
\hline
\end{tabular}

${ }^{*} \mathrm{p}=\mathbf{0 , 0 0 0 0}$

Fonte: Estudo SABE, 2006.

A mudança de credo religioso com o avançar da idade foi estatisticamente significante. De modo geral, houve uma maior migração para a religião católica e, o contrário foi o menos expressivo. Apenas 5,0\% 
dos que se referiram católicos em 2000, mudaram seu credo religioso no período. Entre os que referiram algum credo, os que mais mudaram no período foram os espíritas $(57,5 \%)$ seguidos pelos que referiram outros credos (42,4\%), orientais/budistas $(39,6 \%)$ e evangélicos $(11,7 \%)$. É interessante verificar que entre os que referiram não possuir nenhum credo religioso em 2000, pouco mais que a metade migrou para alguma religião $(52,5 \%)$.

Entre as possíveis associações para explicar tais mudanças foram analisados a ocorrência de eventos estressantes como a perda de entes queridos (filhos, cônjuge), mudança na condição de moradia, presença de incapacidade, de sintomas depressivos, sexo e idade (tabela 10).

Tabela 10 - Distribuição (\%) dos idosos segundo mudança de credo religioso no período de 2000 a 2006, segundo sexo, idade, falecimento de filho ou cônjuge, presença de incapacidade e de sintomas depressivos. São Paulo, 2006.

\begin{tabular}{|c|c|c|c|}
\hline & \multicolumn{3}{|c|}{ Mudança de credo religioso entre 2000 e 2006 (\%) } \\
\hline & Não & Sim & $p$ \\
\hline \multicolumn{4}{|l|}{ Sexo } \\
\hline Homem & $91,8(n=379)$ & $8,2(n=33)$ & \multirow{3}{*}{0,2700} \\
\hline Mulher & $89,7(n=631)$ & $10,3(n=69)$ & \\
\hline \multicolumn{3}{|l|}{ Idade } & \\
\hline 65 a 74 & $90,1(n=636)$ & $9,9(n=71)$ & \multirow{3}{*}{0,1492} \\
\hline 75 e mais & $93,0(n=374)$ & $7,0(n=31)$ & \\
\hline \multicolumn{3}{|c|}{ Falecimento de filho } & \\
\hline Sim & $90,8(n=118)$ & $9,2(n=14)$ & \multirow{2}{*}{0,8804} \\
\hline Não & $91,2(n=820)$ & $8,8(n=74)$ & \\
\hline \multicolumn{4}{|c|}{ Falecimento de cônjuge } \\
\hline Sim & $83,9(n=37)$ & $16,1(n=7)$ & \multirow{2}{*}{0,1342} \\
\hline Não & $91,2(n=930)$ & $8,8(n=87)$ & \\
\hline \multicolumn{4}{|c|}{ Arranjo unipessoal } \\
\hline $\operatorname{Sim}$ & $85,9(n=174)$ & $14,1(n=25)$ & \multirow{2}{*}{0,0521} \\
\hline Não & $91,6(n=835)$ & $8,4(n=75)$ & \\
\hline \multicolumn{4}{|c|}{ Dificuldade no desempenho de ABVDs } \\
\hline Sim & $90,8(n=340)$ & $9,19(n=30)$ & \multirow{2}{*}{0,8794} \\
\hline Não & $90,4(n=670)$ & $9,6(n=72)$ & \\
\hline \multicolumn{4}{|c|}{ Dificuldade no desempenho de AIVDs } \\
\hline Sim & $89,7(n=484)$ & $10,3(n=50)$ & \multirow{2}{*}{0,5383} \\
\hline Não & $91,0(n=526))$ & $9,0(n=52)$ & \\
\hline \multicolumn{4}{|c|}{ Sintomas depressivos } \\
\hline Sim & $87,7(n=101)$ & $12,3(n=12)$ & \multirow{2}{*}{0,3882} \\
\hline Não & $90,8(n=909)$ & $9,2(n=90)$ & \\
\hline
\end{tabular}

Fonte: Estudo SABE, 2006. 
Verifica-se que nenhum dos eventos analisados foi estatisticamente significativo. Houve uma aproximação maior entre os que referiram residir em arranjos unipessoais e mudar de credo. 
Discussão 


\section{DISCUSSÃO}

A religião é um dos objetos mais complexos de investigação, visto que, como fenômeno humano, ela é ao mesmo tempo experencial, psicológica, sociológica, antropológica, histórica, política, teológica e filosófica $^{44}$.

A religiosidade é uma das experiências mais marcantes e significativas do cotidiano humano. Estudo realizado pelo Instituto Gallup, em 1996 nos Estados Unidos, 96,0,0\% da população afirmava acreditar em Deus, $90,0 \%$ rezavam, $69,0 \%$ eram membros de igrejas e $43,0 \%$ haviam ido a um culto em uma igreja, sinagoga ou outro templo ${ }^{65}$. Outro estudo realizado pelo mesmo instituto em 2000 , verificou que $88,0 \%$ dos norteamericanos se auto-denominam pessoas religiosas ou espirituais, $83,0 \%$ sentem Deus como importante em suas vidas e apenas 7,0\% afirmam que a espiritualidade não é importante em seu cotidiano ${ }^{66}$.

Entre os brasileiros, a religião também é importante. $92,5 \%$ das pessoas referem ter alguma religião contra apenas $7,3 \%$ que o negam ${ }^{1}$. Resultados encontrados nesse estudo corroboram os dados do censo demográfico, no qual entre os entrevistados, no ano de $2000,97,6 \%$ mencionaram ter uma religião, elevando-se esse percentual para 98\% em 2006.

Além disso, pode se observar uma variedade religiosa ao longo dos anos. De acordo com pesquisa realizada por Jacob ${ }^{67}$ sobre a pluralidade religiosa, segundo dados do IBGE, não houve qualquer mudança religiosa 
significativa entre 1970 e 1980. Porém, a partir deste período (com exceção do ano de 2003, onde há uma pausa na queda daqueles que se referem católicos), os dados do censo mostraram uma diminuição na proporção de católicos e aumento entre os que se declaram sem religião e os evangélicos.

Essas modificações foram também observadas neste estudo, diminuição na proporção dos católicos de 2000 para 2006 e o aumento dos evangélicos/protestantes. Para Antoniazzi ${ }^{68}$, a diminuição da porcentagem de católicos pode estar associada ao rápido crescimento populacional (migrações religiosas), assim como acredita que "a expansão de uma religião está ligada ao seu dinamismo, sua capacidade de mobilização e à sua estratégia de evangelização".

Verificou-se também um aumento na proporção de idosos que referem outros credos (aumento de 2,5\%). A diversificação religiosa também aparece em estudo realizado em 2007 pelo centro de Pesquisa Social, a partir do processamento de microdados da Pesquisa de Orçamentos Familiares de 2003, que mostra um aumento do surgimento de religiões alternativas de 2,6\% em 2000 para 3,2\% em 2003, chegando a 4,62\% em $2009^{48}$. Almeida ${ }^{52}$ acredita que essa pluralidade esteja relacionada tanto à circulação das pessoas por diversas instituições religiosas, quanto às mudanças ocorridas nas práticas e nas crenças destas ao longo do tempo. Jacob ${ }^{67}$ conclui que essa variedade de religiões pode estar ligada ao avanço de frentes pioneiras, onde pastores pentecostais encontram terreno favorável junto a uma população migrante desenraizada da cultura católica, e concorda com Antoniazzi ${ }^{68}$ a respeito da urbanização acelerada, o que 
favorece o surgimento de novas religiões ou a difusão de religiões vindas de outros países.

Apesar de pequena diminuição nas prevalências no período analisado, ainda se observa a predominância dos católicos e essa distribuição ocorre igualmente em relação ao gênero e a idade (tabela 3), principalmente nos mais idosos. O aumento na proporção dos evangélicos pode ocorrer tanto pela migração de um credo a outro como pela saída - por óbito - dos mais velhos. Dados do estudo realizado pela Fundação Getúlio Vargas em $2010^{48}$ corroboram com os encontrados neste estudo, mostrando as mulheres mais religiosas que os homens, porém menos católicas que eles $(75,3 \%$ no sexo masculino contra $71,3 \%$ para o sexo feminino), o que mostra que enquanto os homens abandonaram as crenças, as mulheres trocaram de crença. Tais mudanças religiosas no universo feminino segundo Neri ${ }^{48}$, podem ser associadas ao não acompanhamento da igreja católica com as novas questões e independência conquistadas pelo universo feminino. Ensaio realizado por Scavone ${ }^{69}$, analisando dados recentes das religiões no Brasil, com base nas pesquisas da Fundação Getúlio Vargas e Datafolha (ambas em 2007), também mostra a igreja católica cedendo lugar para outras religiões (principalmente para os evangélicos), além de uma perda de fiéis do sexo feminino, quebrando uma longa tradição de que estas sempre foram mais numerosas que os homens dentro do catolicismo. A migração das mulheres para os cultos evangélicos (e outros cultos) para ele pode ser explicada pelo fato de que ao mesmo tempo que esta oferece uma resposta mais imediata em relação aos seus 
problemas pessoais e familiares, ela reafirma o lugar tradicional das mulheres na sociedade ${ }^{69}$.

No Brasil 89\% de sua população concorda com a importância dada à religião, o que o coloca em $60^{\circ}$ lugar quando comparado com outras nações 48 .

As mulheres referem-se mais religiosas que os homens e dão mais importância à religião tanto em 2000 como em 2006 (p<0,05) (tabelas 3 e 5). Para Miller e Stark ${ }^{70}$, tal fato pode ser explicado pelos papéis atribuídos às mulheres durante a vida. Desde meninas elas seriam educadas para serem mais passivas e submissas, exercendo atividades como criar, cuidar e educar, facilitando a aceitação de crenças e o envolvimento religioso. Além disso, é responsabilidade da mulher adulta em transferir aos filhos valores morais e preocupar-se com seu bem-estar espiritual. A flexibilidade de tempo permitida pelo trabalho doméstico também seriam fatores associados à prática e envolvimento religiosos mais intensos.

Scavone ${ }^{69}$ acredita que 0 conforto buscado na religião pelas mulheres esteja voltado à necessidade de serem ouvidas e de serem socialmente reconhecidas, seja por expressões de angústia da alma ou pela necessidade da crença ou busca pela salvação. Estudo longitudinal realizado com americanos entre 2002 e 2006, através de entrevista telefônica com mais de 11.000 adultos escolhidos de forma aleatória, encontrou resultados muito semelhantes ao desse estudo em relação a importância dada a religião. Em cada 10 norte-americanos, 6 consideraram a religião muito importante em suas vidas e, em relação ao gênero, talvez ela 
seja observada com maior freqüência entre as mulheres por estas viverem em média mais que os homens ${ }^{66}$.

A mesma pesquisa apresenta uma correlação direta da religião com a idade, demonstrando que $70 \%$ dos idosos de 65 anos e mais velhos referem ser a religião muito importante em sua vida, enquanto apenas $9 \%$ não a consideram. Os autores acreditam que os idosos têm razões funcionais ou racionais para abraçar a religião, uma vez que tenham mais frustrações e tristezas na vida e que estejam se aproximando do desfecho da morte ${ }^{66}$.

Neri ${ }^{48}$ afirma que as pessoas se tornem mais religiosas à medida que se aproximam do final de suas vidas e demonstra isso através da avaliação da trajetória religiosa de cada geração. Em 2009, aqueles que têm 60 anos hoje correspondiam a uma taxa de participação dos sem religião de apenas 3\%. Olhando esta geração há 10 anos, quando tinham entre 50 e 59 anos, a falta de religiosidade encontrava-se em 4,95\% contra 1,99\% quando estavam com 30 a 39 anos (1980) e 0,37\% em 1950, quando tinham entre 0 e 9 anos, o que mostra que de forma geral, a taxa da não religião estava aumentando ao longo do ciclo de vida desta geração ${ }^{48 .}$

O estado marital tem sido outro fator capaz de influenciar a religiosidade dos idosos, podendo-se notar resultado estatisticamente significativo em $2000(p<0,05)$, com predominância entre os idosos viúvos, o que se mantém em 2006 (tabela 3). A importância dada à religião também é predominante entre os viúvos em 2000, porém mostra-se presente em maior número entre os divorciados em 2006 (tabela 5). Brown et al ${ }^{71}$ relatam que diferentes estudos mostram aumento da religiosidade após a morte do 
cônjuge. Tôrres ${ }^{72}$, em seu estudo sobre a viuvez na vida dos idosos em uma Universidade Aberta à Terceira Idade em Feira de Santana (BA), com 32 idosos a partir de 55 anos, mostra que a religião contribuiu muito para a superação da perda do cônjuge, além de ser vista como uma espécie de refugio para a solidão. Benjamins ${ }^{73}$ acredita que a religião seja mais eficaz para pessoas que necessitem de outra fonte de apoio, ou seja, indivíduos casados e com filhos tendem a ter mais apoio do que indivíduos que não contam com isso, como os idosos, que são menos propensos a se casarem e mais provável que vivam sozinhos, o que tornaria o efeito da religião sobre suas vidas maior para esta população.

A escolaridade não foi um fator significativo quanto a referir ou não a uma religião, sendo os não religiosos encontrados principalmente entre aqueles que possuem mais anos de estudo. Em contrapartida, a religião é considerada importante principalmente para os analfabetos em 2000 $(p<0,0002)$ e para aqueles com menor escolaridade em 2006 (tabela 5), o que condiz com a pesquisa norte-americana ${ }^{74}$, que mostra que auto-relatos sobre a importância da religião são menores entre aqueles com educação superior e de pós-graduaçao do que aqueles com ensino médio ou inferior. O mesmo ocorre com relação à renda, quanto maior, menor a importância dada à religião. Essa relação também foi encontrada nesse estudo. Em pesquisa realizada por Neri ${ }^{48}$ há certa diferença em relação ao aspecto educacional e econômico quando comparado ao aqui encontrado, onde a religiosidade é menor nos extremos do espectro educacional e a opção por outras religiões é mais presente no extremo mais alto da educação, sendo o 
espiritismo a principal escolha entre eles. Em relação aos aspectos econômicos, a classe mais baixa aparece como a menos religiosa.

Atualmente, a atenção ao aspecto da religiosidade e da espiritualidade se torna cada vez mais importante na prática da assistência à saúde. Dados apresentados na tabela 4 mostram que, em 2000, o maior número de idosos que refere ter uma religião encontra-se entre aqueles que não referem doenças e avaliam sua saúde como boa. Porém, ao longo dos anos, pode-se notar que a religião passa a estar presente principalmente entre aqueles que referem duas ou mais doenças e avaliam sua saúde como regular.

O mesmo ocorre com a importância dada à religião; enquanto em 2000 os que avaliam sua saúde como boa a consideram importante, em 2006 isso também passa a ser mais importante para aqueles que já apresentam estado de saúde regular (tabela 6). Com a instalação de enfermidades e o passar dos anos, a religião também passa a ser considerada mais importante. Para Faria e Seidl ${ }^{13}$ diante da presença de alguma doença, as práticas religiosas podem atuar como uma intervenção positiva no sentido de favorecer a adaptação do idoso a sua condição de saúde e ao enfrentamento de eventos adversos. McCauley et al ${ }^{75}$. em pesquisa com pacientes com doenças crônicas mostram que idosos com artrite que cultivavam um maior número de experiências espirituais diárias possuíam maior energia e menos sintomas depressivos. Guimarães e Avezum ${ }^{15}$, ao avaliarem o impacto da espiritualidade na saúde física, apresentam pesquisas em que são observadas a redução de níveis 
estressores, depressão e queda da mortalidade em indivíduos com práticas religiosas, estando esta última associada à aquisição de hábitos saudáveis como interrupção do tabagismo, atividade física regular, suporte social e manutenção do estado matrimonial.

A ausência de dificuldades no desempenho das atividades cotidianas (ABVD e AIVD) permite que os idosos consigam freqüentar cultos e realizar seus rituais religiosos com maior facilidade, sem depender de outra pessoa, o que talvez explique o fato de que aqueles capazes de realizarem tais atividades sejam mais religiosos, assim como aqueles que não apresentam declínio cognitivo (tabela 4).

Apesar de a importância da religião não ter sido significante para os idosos que tem dificuldade funcionais, ela foi mais valorizada em 2000 entre aqueles que encontram obstáculos para execução dessas atividades, resultado este que se inverte em 2006 para as ABVD e que corrobora com pesquisa realizada por Benjamins ${ }^{73}$ em 2004, com 4071 idosos não institucionalizados a respeito da relação entre a limitação funcional e a atividade religiosa, que mostra que a religião é considerada mais importante para aqueles que apresentam maior número de limitações funcionais.

A depressão, que aparece como uma das desordens mais comuns entre os idosos, tem se mostrado como um importante problema de saúde pública, apresentando-se como uma mais importantes doenças da atualidade. Em revisão bibliográfica realizada em países desenvolvidos por Pinho, Custódio e Makdisse ${ }^{76}$, em países desenvolvidos, verificou-se que a prevalência da depressão em idosos ocorre, principalmente, nos idosos 
cognitivamente saudáveis e residentes em Instituições de Longa Permanência para Idosos (ILPIs) $(60,0 \%)$, seguido pelos portadores de doenças crônicas hospitalizados ou por aqueles atendidos em unidades de atenção primária (25,0\% aproximadamente) e, por último, os residentes na comunidade $(10,0 \%)$. Isso condiz com estudo realizado com dados da Pesquisa Nacional por Amostra de Domicílios (PNAD) ${ }^{77}$ de 1998, que numa amostra de 344975 pessoas entrevistadas, das quais 28943 são idosas, foi observou-se que entre essas, $12,5 \%$ referiram ter depressão, o que também foi encontrado no Estudo SABE, estando esta doença presente em 14,1\% dos idosos em 2006 e em 19,0\%, em 2000.

Percebe-se que em 2006 a relação entre ter depressão e referir uma doença foi estatisticamente significativa $(p=0,0318)$, diferentemente de 2000 (tabela 4), o que também ocorre quando observado sobre a importância dada a religião (tabela 6) em relação aos idosos depressivos. Diversos estudos têm demonstrado a relação positiva entre esses dois conceitos. Koening e colaboradosres ${ }^{78}$ avaliaram idosos homens internados em um hospital e verificaram que aqueles que se sentiam mais apoiados pela religião apresentavam menor freqüência de depressão. Em outro estudo de revisão entre a relação depressão, religião e religiosidade, Koening e Larson 79 observaram que mais da metade dos trabalhos encontrados apontavam menor prevalência de transtornos ou sintomas depressivos em pessoas religiosas. Koening, MCCullough e Larson ${ }^{54}$, que resumiram pesquisas relacionando religiosidade e quadros depressivos, mostram que pessoas que não são afiliadas a instituições religiosas têm maior risco para desenvolver sintomas e distúrbios depressivos, assim como estudo realizado 
por Drucker ${ }^{80}$, que mostra interferência positiva da religião para melhora da depressão.

A religião mostrou-se significante em relação ao declínio cognitivo em 2000 (Tabela 4), o que presume-se que possa ocorrer devido as pessoas que não apresentam nenhum déficit cognitivo terem maior possibilidade de se auto-referirem mais religiosas ou se apegarem mais a uma religião, porém, tal resultado não mostra diferença em 2006, assim como nesse mesmo período é dado maior importância à religião por aqueles que apresentam declínio cognitivo. Machado et al ${ }^{81}$ realizou um estudo com 74 idosos (com 60 anos ou mais) freqüentadores do Programa Municipal da Terceira Idade na cidade de Viçosa - MG, com o objetivo de avaliar o declínio cognitivo e destaca a importância do lazer e da sociabilidade nessa faixa etária, que considerados indicadores de qualidade de vida, acabam por influenciar nas condições de saúde. Entre as atividades de lazer, a prática religiosa foi uma das mais citadas por esse grupo pois permitia estabelecer um relacionamento social fora do ambiente familiar, facilitando a interação com novas amizades e permitindo a troca de experiências, o que favorece seu bem-estar e autonomia, auxiliando-os a vencer com mais facilidade as dificuldades dessa etapa da vida.

A freqüência ao culto religioso mostra-se significativamente importante em relação ao sexo e a faixa etária $(p<0,05)$ (tabela 7$)$. A maior presença de mulheres e de idosos mais jovens nos cultos religiosos pode estar associada ao fato de elas serem mais religiosas do que eles e pelo número de limitações adquiridas com o avançar da idade. Estudo realizado 
por Drucker ${ }^{80}$ aponta associação positiva entre atividades religiosas e a depressão, principalmente nas atividades de ir à igreja e rezar, o que também condiz com estudo de Benjamins ${ }^{73}$.

Araujo et al ${ }^{82}$ realizaram estudo com 419 idosos com idade igual ou superior a 60 anos, nos municípios de Fortaleza, Baturite, Juazeiro do Norte e Quixadá, entre 2005 e 2006, com o objetivo de verificar a importância da religiosidade entre essa população e assim como neste trabalho, observaram que grande parte dos entrevistados apontou a opção rezar/orar como principal atividade realizada para divertimento próprio, além de que mais da metade dos idosos se dedica ao lado espiritual diariamente e não apenas quando em situação de sofrimento, concluindo assim que a religiosidade é um fator importante para um envelhecimento saudável e, principalmente, para que o idoso lide melhor com a finitude.

O envolvimento religioso parece ter significativo efeito protetor para o bem estar físico e emocional de pessoas que estão enfrentando situações de crise. Segundo Santana ${ }^{9}$, a religião pode servir como apoio para 0 enfrentamento de problemas do cotidiano e auxílio na busca de satisfação de desejos e necessidades. Ele acredita ainda que ela é vista como fonte de significado por satisfazer as pessoas em suas necessidades básicas do cotidiano, fortalecer a fé, os dogmas e crenças sobre a imortalidade, além de fazer com que estas acreditem no divino, no sobrenatural. Dados encontrados neste estudo mostram que a religião ajuda principalmente as mulheres e os mais idosos a entender e a enfrentar as dificuldades da vida diária, assim como fornece sentido a sua vida (tabela 8). Para Fortes ${ }^{83}$, 
estas utilizam mais frequentemente recursos como a oração, a fé, e a confiança em Deus ou num ser superior, enquanto que os homens mostramse mais inibidos quanto as suas emoções diante de situações mais estressantes. Entre os americanos, a grande maioria dos que freqüentam a igreja ou outro serviço de culto semanal $(82,0 \%)$ dizem que a religião pode responder aos problemas atuais ${ }^{84}$.

Para Starling ${ }^{85}$, estar inserido em um grupo social religioso retarda 0 envelhecimento, uma vez que a religião promove suporte social, além de satisfazer e justificar um sentido para a vida. Estudo realizado com idosos por Cardoso ${ }^{86}$ com o intuito de avaliar as inter-relações do envolvimento religioso com o bem estar subjetivo em idosos revela que a religião e a religiosidade desempenham importante papel no ambiente social, pois atuam tanto em nível cognitivo quanto afetivo, oferecendo suporte emocional, espiritual e social, promovendo o bem estar na velhice.

Araujo et al ${ }^{82}$ referem que ao lidar com fatos não-controláveis os idosos utilizam a fé como suporte para superação dos momentos difíceis do cotidiano e completa ainda que o uso da religiosidade para superar as dificuldades da vida não faz sentido se as crenças não forem intrínsecas à pessoa idosa.

A mudança de credo religioso observada entre 2000 e 2006 e suas possíveis causas também foram analisados e mostraram-se estatisticamente significativas (tabela 9), mostrando uma migração dos católicos para todas as outras religiões e como principal receptor de fiéis. Coelho ${ }^{87}$ em estudo sobre o trânsito religioso no Brasil mostra o catolicismo como doador 
universal de fiéis, onde estes migram primeiramente para os evangélicos e posteriormente para os "sem religião", enquanto que por outro lado, ele recepciona fiéis principalmente do grupo dos "sem religião" e em seguida dos evangélicos, o que seria explicado pelo delicado limite existente entre os chamados "católicos não-praticantes" e os "sem religião". Tais dados divergem em alguns aspectos dos aqui encontrados, que mostram os católicos recendo fiéis principalmente dos "sem religião", daqueles pertencentes a "outras religiões", dos espíritas, dos orientais/budistas e por fim, dos evangélicos.

Pesquisa realizada pelo Centro de Estatística Religiosa e Investigações Sociais (CERIS) ${ }^{88}$ em seis cidades brasileiras (Rio de Janeiro, São Paulo, Porto Alegre, Recife, Salvador e Belo Horizonte), verificou que $23 \%$ dos católicos frequentam cultos de outras religiões e $36 \%$ acreditam na reencarnação, elemento central de religiões espiritualistas.

A transição entre religiões, nos dias atuais, é facilitada pelo fato de a mudança religiosa ser melhor aceita pela sociedade, mesmo pelos indivíduos mais velhos, o que favorece a diversidade das crenças no Brasil.

Com o intuito de se investigar as razões da mudança religiosa, dados como o sexo, idade, condições de moradia e fatores estressantes como perda de filho e cônjuge, presença de incapacidades e depressão foram avaliados, porém, nenhum desses fatores foi significante para esta mudança com o decorrer da idade (tabela 10). Pesquisa realizada pelo CERIS em 2004 em 50 municípios brasileiros, com 2870 questionários respondidos com o objetivo de identificar os motivos e as características da mudança de 
religião da população brasileira, encontrou que tal fenômeno ocorre por discordância com a doutrina religiosa (motivo pelo qual 35\% abandonaram o catolicismo, $13,9 \%$ dos evangélicos e $33,3 \%$ daqueles que vieram de "outras religiões"), influência de amigos e parentes (principalmente no catolicismo), falta de apoio da religião anterior em momentos de dificuldades pessoais (mais citado entre os evangélicos) e falta de acolhimento, aproximação com Deus e bem-estar dentro de um determinado grupo religioso (resultado presente principalmente entre os católicos - 33,8\% - e entre os evangélicos - 31,3\%), a busca da religião como instituição capaz de auxiliá-los em momentos de dificuldades e a necessidade de encontrar um espaço ético. Além disso, tal pesquisa mostra um maior trânsito religioso entre os divorciados $(52,2 \%)$ e os separados judicialmente $(35,5 \%)^{89}$. 
Conclusões 


\section{CONCLUSÕES}

Esta pesquisa permitiu chegar às seguintes conclusões:

- A maioria dos idosos são católicos, seguido pelos evangélicos e espíritas respectivamente, sendo o sexo feminino predominante em todas as religiões ( $p=0,0001$ ), com exceção dos católicos e judeus;

- Em relação à idade, os idosos mais jovens procuraram mais outras religiões em $2006(3,6 \%)$ do que em $2000(0,6 \%)$, enquanto os mais idosos se mostraram mais religiosos com o decorrer dos anos $(2,4 \%$ dos idosos sem religião em 2000 e 1,4\% em 2006);

- A religião esteve presente na vida da maioria dos idosos em $2000(97,6 \%)$ e se manteve em 2006 (98\%), predominantemente entre as mulheres ( $p=0,0000$ em 2000 e $p=0,0155$ em 2006), os viúvos ( $p=0,0426$ em 2000) e aqueles com escolaridade intermediária em ambos os momentos de avaliação,

- Ao se analisar a presença ou não de religião referida relacionada à condição de saúde, não houve alterações no perfil religioso ao se comparar 2000 com 2006, quando avaliados o número de doenças, a presença de sintomas depressivos e a dificuldade no desempenho das atividades cotidianas (ABVDs e AIVDs), porém quando avaliada a auto-percepção de saúde, em 2000, os idosos que referiram pertencer a alguma religião referiram excelente condição de saúde (97,9\%) enquanto que em 2006 a maioria dos idosos referiu regular condição de saúde (99,4\%). O mesmo ocorreu quando 
avaliado o declínio cognitivo, onde a maioria dos idosos que referia um credo religioso em 2000 não apresentava declínio cognitivo (97,9\%) e em 2006, esse resultado se inverte (98,8\% de idosos com declínio cognitivo);

- A religião foi considerada importante em todas as variáveis analisadas tanto em 2000 como em 2006, sendo possível observar que sua importância se elevou ao longo dos anos. Além disso, ela foi considerada mais importante para as mulheres ( $p=0,0000$ em 2000 e $p=0,0013$ em 2006), para os mais idosos, para os viúvos em 2000 ( $p=0,0473$ ) e os divorciados em 2006, para os que residem sozinhos, os analfabetos ( $p=0,0002$ em 2000) e para aqueles sem renda salarial.

- Quando a importância da religião foi avaliada em relação à condição de saúde, ela se mostrou mais importante para aqueles que referem excelente condição de saúde em 2000 ( $p=0,0184)$ e para os que referem regular condição de saúde em 2006 ( $p=0,0348$ ), enquanto que quando os sintomas depressivos foram avaliados em 2000 a religião era mais importante para os não depressivos, porém em 2006, esse resultado se inverte. Por fim, percebe-se que a religião ao longo dos anos passou a ter maior influência na condição de saúde dos idosos.

- Verificou-se que a religião fornece forças para o enfrentamento de dificuldades $(89,3 \%)$, ajuda a entender as dificuldades da vida diária $(87,2 \%)$, oferece sentido a vida dos idosos $(87,9 \%)$, estimula sua inserção social, oferece conforto, auxilia na promoção da saúde e promove o bemestar. 
O presente estudo teve a finalidade de mostrar a importância da religião na vida dos idosos e sua associação com algumas condições de saúde/doença. Espera-se que com os resultados aqui encontrados, novas discussões sejam fomentadas com o intuito de se estudar cada vez mais o assunto, permitindo assim que profissionais considerem a religião como fonte de melhoria na qualidade de vida dos idosos. 
Referências 


\section{REFERÊNCIAS}

1. Instituto Brasileiro de Geografia e Estatística (IBGE). Perfil dos idosos responsáveis pelos domicílios no Brasil 2000. IBGE [Internet]. 2002 (Estudos e Pesquisas: Informação Demográfica e Socioeconômica, 9). [acesso em 2008 Maio 05];9. Disponível em: http://www.ibge.gov.br/home/estatistica/populacao/perfilidoso/perfidos os2000.pdf.

2. Carvalho Filho ET, Papaléo M Neto. Geriatria: fundamentos, clínica e terapêutica. São Paulo: Atheneu; 2005.

3. Lebrão ML, Duarte YAO. SABE: Saúde, Bem-estar e Envelhecimento: O Projeto SABE no município de São Paulo: uma abordagem inicial. Brasília: Organização Pan-Americana da Saúde; 2003.

4. Wong LLR, Carvalho JA. O rápido processo de envelhecimento populacional do Brasil: sérios desafios para as políticas públicas. $R$. Bras Est Pop [periódico na internet]. 2006 Jan/Jun [acesso em 2008 mar $12 \quad$ ];23(1):5-26. Disponível em: http://www.scielo.br/pdf/rbepop/v23n1/v23n1a02.pdf

5. Gragnolati M, Jorgensen $\mathrm{OH}$, Rocha R, Fruttero A. Envelhecendo em um Brasil mais velho: Implicações do envelhecimento populacional para o crescimento econômico, a redução da pobreza, as finanças públicas e a prestação de serviços. Banco Internacional para a Reconstrução e o Desenvolvimento / Banco Mundial, 2011.

6. Organização Mundial da Saúde (OMS). Cuidados inovadores para condições crônicas: componentes estruturais de ação: relatório mundial [internet]. 2003 [acesso em 2009 dez 26]. Disponível em: http://www.opas.org.br/publicmo.cfm?codigo $=62$ 
7. Potter PA, Perry AG. Fundamentos de enfermagem. $5^{\mathrm{a}}$ ed. Rio de Janeiro: Guanabara Koogan; 2004.

8. Berger L, Mailloux-Poirier M. Pessoas idosas: uma abordagem global. Lisboa: Lusodidacta; 1995.

9. Santana MC. Significados de religiosidade segundo idosos residentes na comunidade: dados do PENSA. [dissertação]. Campinas: Universidade Estadual de Campinas; 2006.

10. Crawford R. O que é religião? Tradução de Gentil Avelino Titton. Petrópolis: Vozes; 2005.

11. Simpson JA, Weiner ES. The oxford english dictionary. $2^{\text {nd }}$ ed. Oxford: Clarendon Press; 1989.

12. James W. As variedades da experiência religiosa: um estudo sobre a natureza humana. São Paulo: Cultrix; 1995.

13. Faria JB, Seidl EMF. Religiosidade e enfrentamento em contextos de saúde e doença: revisão de literatura. Psicol Reflex Crít. [periódico na internet]. 2005 [acesso em 2008 Abr 18];18(3):381-389. Disponível em: http://www.scielo.br/pdf/prc/v18n3/a12v18n3.pdf

14. Fleck MPA, Borges ZN, Bolognesi G, Rocha NS. Desenvolvimento do WHOQOL, módulo espiritualidade, religiosidade e crenças pessoais. Rev. Saúde Pública [periódico na internet]. 2003 Ago [acesso em 2008 Mar 08],37(4):446-455. Disponível em: http://www.scielo.br/scielo.php?script=sci arttext\&pid=S003489102003000400009\&lng=pt\&nrm=iso.doi:10.1590/S0034$\underline{89102003000400009}$

15. Guimarães HP, Avezum Á. O impacto da espiritualidade na saúde física: revisão de literatura. Rev Psiquiatr Clín [periódico na internet]. 2007 [acesso em 2008 Mar 25];34:88-94. Disponível em: http://www.hcnet.usp.br/ipq/revista/vol34/s1/88.html 
16. Puchalski C, Romer AL. Taking a spiritual history allows clinicians to understand patients more fully. J Palliat Med. 2000;3:129-137.

17. Worthington EL Jr, Kurusu TA, McCullough ME. Empirical research on psychotherapeutic processes and outcomes: a 10-year review and research prospectus. Psychol Bull. 1996;119(3):448-487.

18. Negreiros TCGM. Espiritualidade: desejo de eternidade ou sinal de maturidade? Rev Mal-Estar Subj. [periódico na internet]. 2003 Set [acesso em 2008 Jun 10];3(2):275-291. Disponível em: http://www.unifor.br/notitia/file/156.pdf

19. Durkheim E. Formas elementares da vida religiosa. São Paulo: Abril; 1983.

20. Silva WAS. Religião e sociedade contemporânea: uma análise da religião no mundo atual. Aparecida do Taboado: Secretaria Municipal da Educação, Cultura, Desporto e Lazer de Aparecida do Taboado; 2007.

21. Santridián PR. Dicionário básico das religiões. São Paulo: Santuário; 1996.

22. Gaarder J, Hellern V, Notaker H. O Livro das religiões. São Paulo: Companhia das Letras; 2000.

23. Eliade M. Tratado de história das religiões. Tradução de Fernando Tomaz e Natália Nunes. 2ª ed. São Paulo: Martins Fontes; 1998.

24. Albuquerque EB. A história das religiões. In: Usarski F, organizador. O espectro disciplinar da ciência da religião. São Paulo: Paulinas; 2007. p. 19-51.

25. Schmidt BE. A antropologia da religião. In: Usarski $F$, organizador. $O$ espectro disciplinar da ciência da religião. São Paulo: Paulinas; 2007. p. 53-95. 
26. Nunes MJR. A sociologia da religião. In: Usarski F, organizador. O espectro disciplinar da ciência da religião. São Paulo: Paulinas; 2007. p. 97-119.

27. Mondin B. O homem: quem é ele? Elementos de antropologia filosófica. São Paulo: Paulinas; 1980.

28. Lesbaupin I. Marxismo e religião. In: Teixeira F. Sociologia da religião: enfoques teóricos. Petrópolis, RJ: Vozes; 2003. p. 13-35

29. Mariz CL. A sociologia de Max Weber. In: Teixeira F. Sociologia da religião: enfoques teóricos. Petrópolis (RJ): Vozes; 2003. p. 67-88.

30. Pierucci AF. Secularização em Max Weber: da contemporânea serventia de voltarmos a acessar aquele velho sentido. Rev Bras Ci Soc. 1998 Jun;13(37):1-27.

31. Oliveira FL. O campo da sociologia das religiões: secularização versus a "Revanche de Deus". Revista Internacional Interdisciplinar Interthesis [periódico na Internet]. 2005 Jul/Dez [acesso em 2009 Jun 13];2(2):1-14. Disponível em: http://www.periodicos.ufc.br/index.php/interthesis/article/viewFile/724/ 10786

32. Pieruci AF, Prandi R. A realidade social das religiões no Brasil. São Paulo: Hucitec; 1996.

33. Gomez AS. La religión como fenômeno antropológico: elementos constitutivos del fenômeno religioso. Horizonte. 2004;2(4):11-32.

34. Goldman M. Alteridade e experiência: antropologia e teoria etnográfica. Etnográfica. 2006;10(1):161-173.

35. Schlesinger $H$, Porto $H$. Dicionário enciclopédico das religiões. Petrópolis (RJ): Vozes; 1995. 
36. Eicher P. Dicionário de conceitos fundamentais de teologia. São Paulo: Paulus; 1993.

37. André MG, Lopes RP. O Humano, lugar do sagrado. São Paulo: Olho d'Água; 1995.

38. Dierken J. Teologia, ciência da religião e filosofia da religião: definindo suas relações. Veritas. 2009;54(1):113-136.

39. Soares AML. A teologia em diálogo com a ciência da religião. In: Usarski $F$, organizador. O espectro disciplinar da ciência da religião. São Paulo: Paulinas; 2007.

40. Rodrigues CLR. Psicologia da Religião na investigação científica da atualidade. Ciências da Religião - História e Sociedade. 2008;6(2):36p.

41. Valle E. Psicologia e Experiência Religiosa. São Paulo: Loyola; 1998.

42. Paiva GJ, Zangari W, Verdade $M M$ et al. Psicologia da Religião no Brasil: a produção em periódicos e livros. Psic Teor Pesq. [periodic na Internet]. 2009 Set [acesso em 2010 Jul 14];25(3):[aproximadamente 6 p.]. Disponível em: <http://www.scielo.br/scielo.php?script=sci_arttext\&pid=S0102$37722009000300019 \&$ Ing $=$ en\&nrm=iso.

43. Catalan JF. O homem e sua religião: enfoque psicológico. São Paulo: Paulinas; 1999.

44. Dalgalarrondo P. Religião, Psicopatologia \& Saúde Mental. Porto Alegre: Artmed; 2008.

45. Meadow MJ, Kahoe R. Psychology of Religion: religion in individual lives. New York: Harper and Row, 1984.

46. Allport GW. Personalidade. São Paulo: USP; 1973.

47. Farris JR. Psicologia e Religião. In: Caminhando. 2002; 7(1) [9]:23-37. 
48. Novo Mapa das Religiões. Coordenação Marcelo Côrtes Neri. Rio de Janeiro: FGV; 2011.65 p.

49. Ribeiro JC. Os universitários e a transcendência: visão geral, visão local. Revista de Estudos da Religião - REVER [periódico na Internet]. 2004 [acesso em 2008 Ago 05];2:79-119. Disponível em: http://www.pucsp.br/rever/rv2 2004/p ribeiro.pdf

50. Pierucci AF. "Bye, bye, Brasil": o declínio das religiões tradicionais no Censo 2000. Estud Av [periódico na Internet]. 2004 Set/Dez [acesso em 2008 Jul 27];18(52):17-28. Disponível em: http://www.scielo.br/scielo.php?script=sci arttext\&pid=S0103$\underline{40142004000300003 \& \operatorname{lng}=\& \mathrm{nrm}=\text { iso }}$

51. Couto MT. Pluralismo religioso em famílias populares: poder, gênero e reprodução. [dissertação]. Recife: Universidade Federal de Pernambuco; 2001.

52. Almeida R, Monteiro P. Trânsito religioso no Brasil. Perspec [periódico na Internet]. 2001 Jul/Set [acesso em 2008 Ago 18];15(3):92-101. Disponível em: http://www.scielo.br/pdf/spp/v15n3/a12v15n3.pdf

53. Moreira-Almeida A, Neto FL, Koenig HG. Religiousness and mental health: a review. Rev Bras Priquiatr. 2006;28(3):242-50.

54. Koenig HG, McCullouch ME, Larson, DB. Handbook of religion and health. New York: Oxford University Press; 2001.

55. Goldstein LL. Desenvolvimento do adulto e religiosidade: uma questão de fé. In: Néri, AL, organizador. Qualidade de vida e idade madura. Campinas: Papirus; 1993. p. 83-108.

56. Sinnot JD, Shifren K. Gender and aging: gender differences and gender roles. In: Birren JE, Schaie WK. Handbook of the psychology of aging. San Diego: Academic Press; 2001. 
57. Koenig HG, George LK, Titus P. Religion, spirituality, an health in medically ill hospitalizad older patients. J Am Geriatr Soc. 2004;52(4):554-62.

58. Koenig HG. Religion an health in later life: aging, spirituality, and religion. [S.I.]: Handbook; 1995.

59. Botelho JB. Medicina e religião: conflito de competência. Manaus: Metro Cúbico; 1991.

60. Pessini L. A Espiritualidade interpretada pelas ciências e pela saúde. Mundo Saúde. 2007 Abr;31(2):187-195.

61. Rosa MI, Silva FR, Silva NC. A Oração intercessória no alívio de doenças. ACM Arq Catarin Med [periódico na Internet]. 2007 [acesso em 2008 Mar 23 ];36(1):103-108. Disponível em: http://www.acm.org.br/revista/pdf/artigos/475.pdf

62. Tosta CE. A prece cura? Brasília Med. 2004;(41):38-45.

63. Pargament KI, Kennel J, Hathaway W et al. Religion and the problemsolving process: three styles of coping. Journal for the Scientific Study of Religion, 27, 90-104, 1988.

64. Lebrão ML, Laurenti R. Saúde, bem estar e envelhecimento: o estudo SABE no município de São Paulo. Rev Bras Epidemiol [periódico na Internet]. 2005 [acesso em 2008 Maio 20];8(2):127-41. Disponível em: http://hygeia.fsp.usp.br/sabe/Artigos site/O Estudo SABE no munici pio de Sao Paulo.pdf

65. Princeton Religion Research Center. Religion in America. Princeton: The Gallup Poll; 1996.

66. Gallup International Millennium Survey, 2000. [acesso em 2011 Nov 17]. Disponível em: http://www.gallupinternational.com.survey15.htm 
67. Jacob CR. A diversificação religiosa. Estud Av [Internet]. 2004 Dez [acesso em 2010 Nov 25];18(52). Disponível em: $<$ http://www.scielo.br/scielo.php?script=sci_arttext\&pid=S0103$40142004000300002 \& \operatorname{lng}=$ en\&nrm=iso $>$.

68. Antoniazzi, A. Por que o panorama religioso no Brasil mudou tanto? Horizonte. 2004; 3(5):13-39.

69. Scavone L. Religiões, Gênero e Feminismo. Revista de Estudos da Religião - REVER. 2008;1-8.

70. Miller AS, Stark R. Gender and religiouness: can socialization explanations be saved? Am J Sociol. 2002;107(6):1399-1423.

71. Brown SL, Nesse RM, House JS et al. Religion and emotional compensation: results from a prospective study of widowhood. Personality and Social Psycology Bulletin. 2004; 30:1165-1174.

72. Tôrres EM. A viuvez na vida dos idosos. [Dissertação de mestrado]. Salvador: Universidade Federal da Bahia, Programa de PósGraduação da Escola de Enfermagem; 2006.

73. Benjamins MR. Religion and Functional Health Among the Elderly: Is There a Relationship and Is It Constant? J Aging Health. 2004; 16: 355.

74. Gallup (pesquisa) Religion Most Important to Blacks, Women, and Older Americans, November 29, 2006. Disponível em: http://www.gallup.com/poll/25585/Religion-Most-Important-BlacksWomen-Older-Americans.aspx. Acessado em 24 de novembro de 2010.

75. McCauley J, Tarpley MJ, Haaz S, Bartlett SJ. Daily spiritual experiences 0 folder adults with and without arthristis and the relationship to health outcomes. Arthritis Care Res. 2007; 59(1):122128. 
76. Pinho $M X$, Custódio $O$, Makdisse $M$. Incidência de depressão e fatores associados em idosos residentes na comunidade: revisão de literatura. Rev Bras Geriatr Gerontol. 2009;12(1):123-140.

77. Instituto Brasileiro de Geografia e Estatística. Pesquisa Nacional por Amostra de Domicílios: Acesso e utilização de serviços de saúde: 1998 : Rio de Janeiro: IBGE, 2000.

78. Koening HG, Cohen HJ, Blazer DG et al. Religious coping and depression among elderly, hospitalized medically ill men. Am J Psychiatr. 1992; 149(2): 1693-700.

79. Koening HG, Larson DB. Religion and mental health: evidence for an association. Int Rev Psychiatry. 2001;13: 67-78.

80. Drucker C. Religiosidade, crença e atitudes em idosos deprimidos: em um serviço de saúde mental de São Paulo. [Dissertação de Mestrado] Campinas, SP: Universidade Estadual de Campinas, Faculdade de Educação; 2005.

81. Machado JC, Ribeiro RCL, Leal PFG et al. Avaliação do declínio cognitivo e sua relação com as características socioeconômicas dos idosos em Viçosa-MG. Rev Bras Epidemiol. 2007;10(4):592-605.

82. Araujo MFM, Almeida MI, Cidrack ML, Queiroz HMC, Pereira MCS, Menezes ZLC. O papel da religiosidade na promoção da saúde do idoso. Rev Bras Promoç Saúde. 2008;21(3):201-8.

83. Fortes ACG. Eventos de vida estressantes, estratégias de enfrentamento e estados depressivos em idosos residentes na comunidade: dados do PENSA [dissertação]. Campinas, SP: Universidade Estadual de Campinas, Faculdade de Educacao, PosGraduacao em Gerontologia; 2005.

84. Saad L. American Believe Religion is Losing Clout: percentage saying influence of religion is slipping. Gallup [Internet]. $2008 \mathrm{Dez}$ [acesso em 
2011 Out 15]. Disponível em:

http://www.gallup.com/poll/113533/Americans-Believe-Religion-

Losing-Clout.aspx.

85. Starling RP. Contingências de reforçamento vagamente definidas: construindo prematuramente a velhice. In: Kerbaury RR, Wielensky RC. Sobre o comportamento e cognição. Santo Andre: Arbites; 1999. p. 221-9.

86. Cardoso MCS, Ferreira MC. Envolvimento Religioso e Bem-Estar Subjetivo em Idosos. Psicol Ciênc Prof. 2009; 29(2):380-93.

87. Coelho LD. Trânsito Religioso: uma revisão exploratória do fenômeno brasileiro. Vox Faifae: Revista de ciências Humanas e Letras das Faculdades Integradas da Fama. Vol. 1, n.1, 2009.

88. Almanaque Abril: Brasil 2005. São Paulo: Abril; 2005.

89. Guglielminetti R. "Mudanças na Fé”. Revista Enfoque. ed 50. [acesso em 2010 dez 02]. Disponível em:

http://www.revistaenfoque.com.br/index.php?edicao $=50 \&$ materia $=170$ 
Anexos 
9 ANEXOS

Anexo 1 - CD Instrumento SABE 2000 
Anexo 2 - CD Instrumento SABE 2006 


\section{Anexo 3 - Parecer do Comitê do CONEP (2000)}

MINISTERIO DA SAUUDE

Conselino Nacional de Saude

Comisgso Nacinnal de Etica em Pesquisa - CONEF

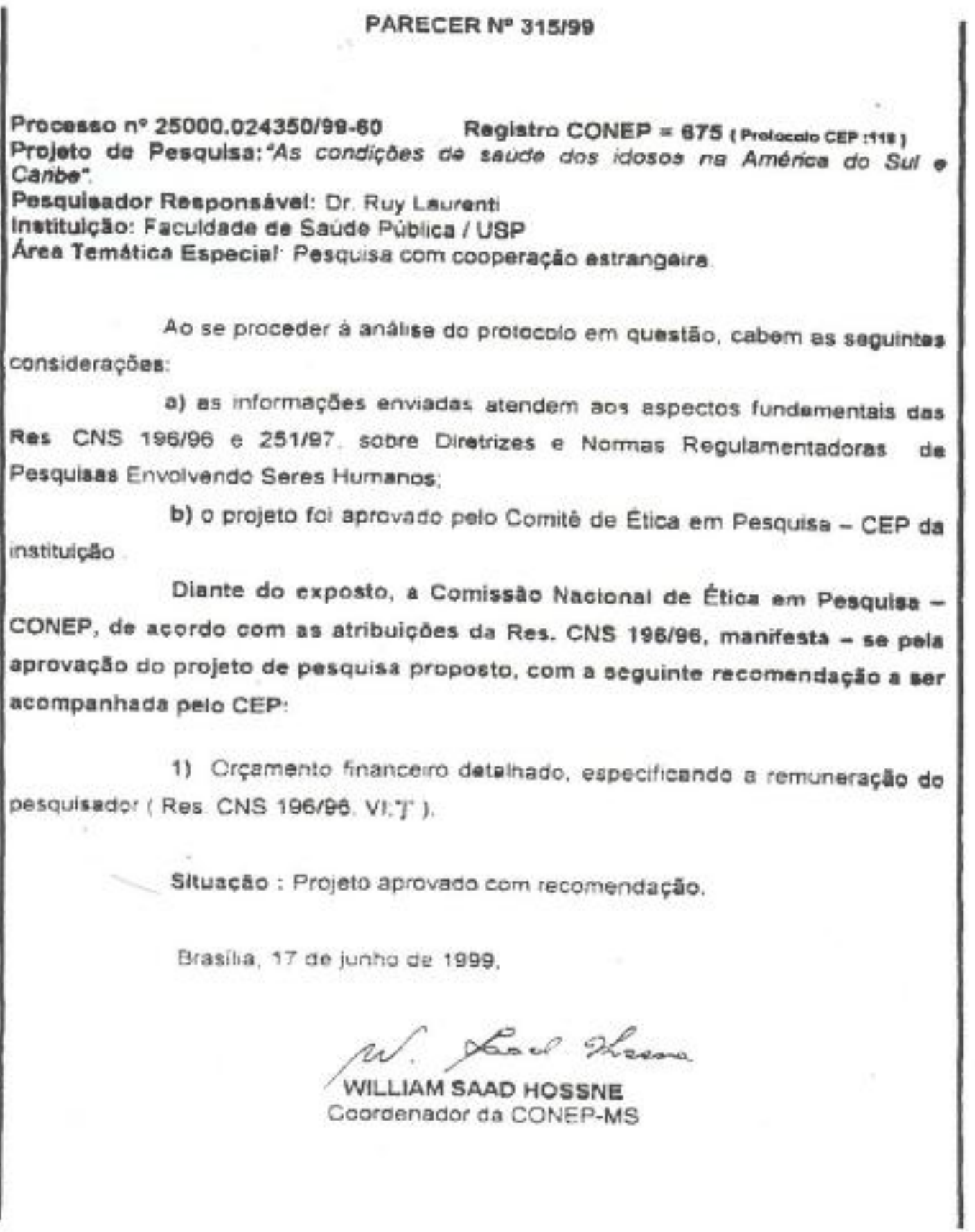




\section{Anexo 4 - Parecer do Comite de Etica da Faculdade de Saude Publica da Universidade de São Paulo (2006)}

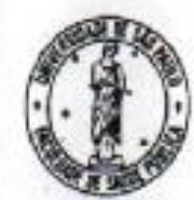

Universidade de São Paulo

Faculdade de Saúde Pública

COMTTÉ DE ÉTICA. COEP

Av. Dr. Amaldes, 715 - Asscossixia Académica - CEP 01246-904 - Sin Paula - Brassil

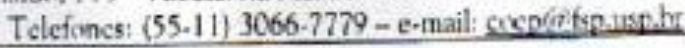

\section{Of.COEP/83/06}

Pelo presente, informo que o Comitè de Ética em Pesquisa da Facuilade de Saúde Pública da Universidade de Sáo Paulo-COEP, aprovou o Protocolo de Pesquisa n. ${ }^{\circ}$ 1345, intitulado: "PROJETO SABE-2005 - SAÚDE, BEM-ESTAR E ENVEUHECMENTO. AS CONDIÇŌES DE SAÚDE E DE VIDA DOS IDOSOS NO MUNICIPIO DE SĀO PAULO", apresentado pela pesquisadora Maria Lúcia Lebrăo.

Atenciosamente,

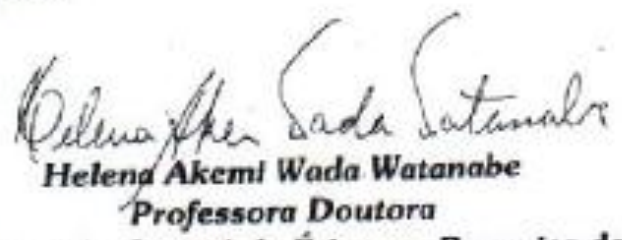

Vlce-Coordenadora do Comitê de Ética em Pesquisa da FSP-COEP 


\section{Anexo 5 - Termo de Consentimento Livre e Esclarecido do Estudo SABE}

\section{Estudo Saúde, Bem-estar e Envelhecimento - SABE}

Por este meio aceito colaborar com o estudo "Saúde, Bem-estar e Envelhecimento"

SABE. OS objetivos principais deste estudo são.

1. Descrever as condiçôes de saúde das pessoas com 60 anos e mais no pais.

2. Avaliar o acesso e utilizaçäo dos serviços cisponiveis para o cuidado da saúde das pessoas com 60 anos e mais, incluindo os näo tradicionais.

3. Definir a contribuição da familia, dos programas de assistència pública e dos recursos privados para satisfazer as necessidades de saúde das pessoas com 60 anos e mais.

Meu consentimento em participar è voluntário, sem coerção ou forço. Também entendo que tenho o direito de terminar a entrevista no momento em que desejar.

Aceito responder un questionário sobre meu estado de saúde e que sejam tomadas minhas medidas como o peso, estatura e gordura corporal. Serão realizados, alén disso. um exame de força muscular manual e umas provas de eficiència fisica (caminhar, agachar, dobrar, levantar e sentar em uma cadeira)

Entendo que serảo tomadas as medidas necessárias para assegurar a confídencialidade de toda informação que eu dé e que não será revelacia minha identidade. Foi-me informado que se eu tiver alguma dúvida ou pergunta adicional sobre este estudo, posso telefonar à Prof" Dr". Maria Lúcia Lebrão, Coordenadora do Estudo nos telefones $3061-7724 / 3061-7744$.

Entendo que näo terei beneficio direto como participante neste estudo nem hà perigo algum por participar do mesmo.

Nöme: Data:

Assinatura: 